\title{
¿Existen derechos sociales?
}

Fernando Atria *

Si un león pudiera hablar, no lo entenderíamos

L. Wittgenstein, Investigaciones Filosóficas (1953)

No hay razón para mantener en suspenso la respuesta a la pregunta que da título a este artículo. Sostendré que si la noción de derecho es entendida por referencia a la idea de derecho subjetivo en el sentido jurídico del término, la noción de derechos sociales es una contradicción en los términos. Si queremos evitar esta conclusión debemos rescatar una forma alternativa de entender el concepto político de derechos. Las líneas que siguen deben ser entendidas como (el inicio de) una contribución a ese respecto.

1. La historia con la que quiero empezar es suficientemente conocida. Durante el siglo XVII, culminando en el siglo XVIII, la burguesía empezó a demandar de modo cada vez más categórico el reconocimiento de ciertos bienes que eran para ella especialmente importantes ${ }^{1}$. El modo en que esa demanda fue formulada fue a través de una exigencia de que ciertos derechos fueran reconocidos. Esos derechos aseguraban a la burguesía protección frente a la arbitrariedad de lo político, ante la voracidad del Leviathan ${ }^{2}$. El reconocimiento de estos derechos fue paulatino, pero hacia fines del siglo

\footnotetext{
* Profesor Asociado de Derecho, Universidad Adolfo Ibáñez. Gracias al profesor Rodrigo Soto por su disponibilidad a examinar una y otra vez muchas de las cuestiones discutidas en este artículo. La versión original de este texto fue presentada como ponencia plenaria en las XVI Jornadas Argentinas de Filosofía Jurídica y Social (Azul, 2002). Versiones posteriores de la misma fueron discutidas en el Seminario organizado por la cátedra del Profesor Marcelo Alegre en la Universidad de Palermo (Buenos Aires, 2003), y en el Congreso de la Asociación Mundial de Filosofía Jurídica y Social (Lund, 2003), en el taller convocado por Rolando Tamayo. Mis agradecimientos a los profesores Ricardo Guibourg, Marcelo Alegre y Rolando Tamayo por la oportunidad para discutir estas ideas en Azul, Buenos Aires y Lund, respectivamente. El autor agradece también el apoyo del Fondo Nacional de Investigación Científica y Tecnológica (FONDECyT), del Gobierno de Chile, al proyecto del cual este artículo es parte (Proyecto 1010461, concurso regular 2001).

${ }^{1}$ cfr. Marshall, Citizenship and Social Class, 8-17 [22-36]. En lo sucesivo, cuando se hace referencia a una obra en su idioma original las referencias a las traducciones españolas, cuando existen y las he tenido a la vista, aparecerán entre corchetes a continuación de la referencia al original.

${ }^{2}$ cfr. Arendt, Orígenes del Totalitarismo, 369.
} 
XVIII la lucha ideológica por establecerlos como bienes a los que las personas tenían título legítimo había sido ganada: sobre la base del reconocimiento de estos derechos, llamados 'civiles y políticos' fue que se estructuró el concepto de estado de derecho. En efecto, las dos notas centrales del estado ('formal') de derecho, el principio de distribución conforme al cual la libertad de los individuos es anterior al Estado y por lo tanto en principio ilimitada, mientras que la facultad del Estado para invadirla es en principio limitada, y el principio de organización, conforme al cual el poder del estado es desmembrado en diversos órganos, se explican y justifican por la necesidad de crear estructuras institucionales que aseguren el goce de esos derechos 'naturales's.

Los derechos de ésta, que después fue llamada 'primera' generación, irrumpieron históricamente de la mano de la revolucionaria idea de que lo político era una asociación no natural, es decir, una asociación constituida por seres humanos de modo artificial ${ }^{4}$. Los derechos eran aquello que los individuos constituyentes de lo político detentaban antes de esa constitución, y que en definitiva justificaba la idea misma de constituir la comunidad política $^{5}$. Por tanto, los derechos fueron concebidos originalmente como derechos del individuo en contra de la comunidad política. 'En contra' tiene aquí un doble sentido: por una parte, eran derechos en contra de la comunidad porque ya constituida ésta, la principal amenaza para los derechos ya no era el ataque de otros individuos (neutralizar esa amenaza era la finalidad del contrato constitutivo), sino el Leviathan recién constituido. Por otra parte, porque los individuos constituyentes (contratantes) eran en algún sentido

\footnotetext{
${ }^{3}$ Sobre las dos notas del estado de derecho, véase Schmitt, Teoría de la Constitución, 138-139. En general, sobre el estado formal de derecho, véase Böckenförde, "Origen y cambio".

${ }^{4}$ En efecto, como sostenía H Arendt, 'la importancia que aún hoy [la idea de el estado de naturaleza] conserva se debe al reconocimiento de que la esfera política no nace automáticamente del hecho de la convivencia y de que se dan acontecimientos que, pese a producirse en un contexto estrictamente histórico, no son auténticamente políticos e incluso puede que no tengan que ver con la política [...]. En efecto, la hipótesis de un estado de naturaleza implica la existencia de un origen que está separado de todo lo que le sigue como por un abismo insalvable'. Arendt, On Revolution, 19 [19-20]. cfr. también Arendt, Orígenes del Totalitarismo, 368.

${ }^{5}$ cfr. Schmitt, Teoría de la Constitución, 167: 'la declaración solemne de derechos fundamentales significa el establecimiento de principios sobre los cuales se apoya la unidad política de un pueblo y cuya vigencia se reconoce como el supuesto más importante del surgimiento y formación incesante de esa unidad'.
} 
acreedores de la comunidad política, cuya existencia era justificada por la protección a los derechos que ella aseguraba.

$Y$ esta fue efectivamente la función política de los derechos: justificar (ex-ante o ex-post) la revolución' ${ }^{6}$ Los derechos eran ya 'la libertad, la propiedad, la seguridad y la resistencia a la opresión', como en el caso francés, o 'la vida, la libertad y la búsqueda de la felicidad', como en el caso norteamericano. El vínculo entre las declaraciones de derechos y la finalidad de la asociación política es en ambos casos explícito: 'el objeto de toda sociedad política es la conservación de los derechos naturales e imprescriptibles del hombre' (art. 2) dijeron los revolucionarios franceses, mientras la tercera verdad autoevidente para los norteamericanos era que 'para proteger estos derechos los hombres instituyen gobiernos'. Los derechos invocados por los revolucionarios eran, en consecuencia, naturales en el sentido de que ellos eran normativamente previos a la existencia de la comunidad política. El respeto a esos derechos se convirtió en el fundamento de la autoridad de los nuevos sistemas políticos modernos?

2. Pero la visión liberal, aunque dominante, no sería la única tradición moderna. Me interesa en particular prestar atención a una de las ideas centrales de las tradiciones republicana y socialista, de acuerdo a la cual el acto constitutivo de lo político crea una comunidad cuyo valor reside no en la protección que ofrece contra la agresión de otros, sino en que posibilita una forma de vida propiamente humana, en la que cada uno ahora puede relacionarse con los otros

substituyendo en su conducta el instinto por la justicia, y dando a sus acciones la moralidad que antes les faltaba. Sólo entonces, cuando la voz del deber sucede al impulso físico y el derecho al apetito, el hombre que hasta entonces no había mirado más que a sí mismo se ve forzado a obrar por otros principios y a consultar su razón antes que escuchar sus inclinaciones 8 .

\footnotetext{
${ }^{6}$ Véase Waldron, "Natural rights in the seventeenth century", 7-13.

${ }^{7}$ Véase Böckenförde, "Origen y cambio", 33. En este párrafo, las referencias son la a Declaración de Independencia Norteamericana (Filadelfia, 1776), y a la francesa Declaración de Derechos del Hombre y del Ciudadano (1789).

${ }^{8}$ Rousseau, Contrato Social, Cap. I.8; nótese cómo lo que el pacto social hace posible es, para Rousseau, que los seres humanos desarrollen una 'capacidad para un sentido de la justicia', que es precisamente lo que para Rawls es condición necesaria y suficiente de la ciudadanía moral (véase Rawls, Theory of Justice, §77). Podríamos también haber hecho referencia a la Grundrisse de Marx: 'El hombre es en el sentido más literal de la palabra un zoon politikon, no sólo un animal social, sino un animal que puede desarrollarse como individuo sólo en sociedad': Marx en McLellan (ed), Marx's Grundrisse 17. cfr. también Waldron, "Karl Marx's 'On the jewish question'“, 128-129.
} 
En la visión liberal son los derechos individuales los que constituyen el núcleo duro de legitimidad. El estado es utilizado como un instrumento para hacer cumplir las obligaciones que los individuos tenían, respecto de los otros, incluso en el estado de naturaleza, y que correspondían a esos derechos naturales. Las obligaciones de los demás (incluido el estado) y los derechos del agente son correlativos, pero la prioridad normativa corresponde a los derechos ${ }^{9}$.

En esta visión socialista o republicana la comunidad es valiosa porque permite a sus miembros relacionarse respondiendo a la razón y no a sus inclinaciones; en otras palabras, porque dentro de ella pueden actuar no ya mirando exclusivamente su auto interés, sino sobre la base de la solidaridad. La idea de solidaridad, expresada comunitariamente en el lema 'de cada cual de acuerdo a sus capacidades, a cada cual de acuerdo a sus necesidades' (que la sociedad comunista inscribiría en sus estandartes después de abolir el derecho burgués ${ }^{10}$ ) es una que enfatiza la obligación comunitaria de atender al bienestar de cada uno de sus miembros. En la correlación derechodeber la prioridad justificatoria se invierte cuando se trata de la idea de solidaridad: la solidaridad no puede ser expresada primariamente en términos de derechos (subjetivos), porque ella

implica la idea de 'tenderle la mano' a la otra persona, un elemento de supresión del yo y sacrificio hacia el otro, y el derecho por su misma naturaleza como un medio de adjudicar

\footnotetext{
${ }^{9} \mathrm{~F}$. Laporta ha sostenido la tesis de la correlatividad entre derechos y deberes implica 'forzosamente' la prioridad justificatoria de los deberes (Laporta, "Concepto de derechos humanos", 25). Pero la tesis de la correlatividad es agnóstica respecto del problema de la prioridad justificatoria, porque sólo afirma que los derechos son correlativos a los deberes. Es curioso que Laporta no haya notado que la tesis de la correlatividad es tan compatible con la idea de que "la noción de "derecho" es reducible a una noción lógicamente más primitiva como es la de "deber" (ibid) como lo es con la idea contraria. Sobre lo que él denomina el 'axioma de la correlatividad' véase el lúcido análisis de Kramer, Rights, 24-49. Una cuestión distinta, por supuesto, es afirmar por otras razones (i.e. razones adicionales a la mera tesis de la correlatividad) la prioridad de deberes sobre derechos, como lo hacen, entre otros, Weil, Echar Raices, 23; O’Neill, Bounds, 98-105, o el propio Kelsen, Teoría Pura, 138-142. En todos estos casos, la afirmación de la prioridad del deber sobre el derecho se basa precisamente en rechazar (al menos parcialmente) la tesis de la correlatividad ('al menos parcialmente' porque la tesis de la correlatividad puede ser entendida en un sentido fuerte: significando que no hay obligaciones sin derechos correlativos ni viceversa, o en un sentido débil: implicando sólo lo segundo pero no lo primero; aceptando, como Kelsen, que puede haber obligaciones sin derechos, aunque no derechos sin obligaciones; véase infra, $\mathrm{n}$. 21). La cuestión de la prioridad no es conceptual sino substantiva: 'el incentivo que funciona en el sistema de libre contrato del mercado abierto es el beneficio personal; el que corresponde a los derechos sociales es el deber público', dice Marshall, Citizenship and Social Class, 43 [74].

${ }^{10}$ Marx, Critique of the Gotha program, 215.
} 
pretensiones en conflicto y el principio de 'ganar o perder' viola el momento de autonegación que subyace al encuentro de la solidaridad ${ }^{11}$.

3. El avance del socialismo durante el siglo XIX y su énfasis en la idea de comunidad e igualdad tuvo su impacto en la idea de 'derechos' y en las antiguas declaraciones. En efecto, desde el punto de vista socialista, el énfasis liberal en los derechos civiles y políticos era unilateral y formalista.

Era unilateral, porque miraba al individuo aislado de la comunidad y dejaba fuera de consideración al individuo situado. La lista de derechos con que los liberales dotaban al individuo era una que quedaba definida naturalmente, sin que la existencia de la (artificial) comunidad política fuera relevante. Por supuesto, como hemos visto, los revolucionarios burgueses creían que los derechos eran relevantes para la asociación política porque la protección de los mismos fijaba su única finalidad legítima, pero el hecho de vivir en comunidad no era fuente de 'derecho' alguno. Esto no era casual, porque si los derechos fueran concebidos como derechos del ciudadano situado ya no sería posible hablar de la verdad autoevidente de que 'para proteger esos derechos los hombres instituyen gobiernos' ${ }^{12}$.

Era formalista, porque enfatizaba la importancia de las condiciones formales para el ejercicio de la libertad y la búsqueda de la felicidad sin pronunciarse acerca de la importancia de las condiciones sustantivas. Pero las interferencias de otros son simplemente una de las causas de los límites a la libertad. Notoriamente, la carencia de recursos es otra causa.

Es importante notar que estas dos características del pensamiento liberal están conectadas entre sí: es precisamente el unilateralismo lo que permite rechazar el cargo de formalismo (al menos cuando es formulado así: como un cargo). Los derechos que hoy llamamos de 'primera' generación tienen una peculiaridad: la especificación completa del contenido del aspecto activo de esos derechos es al mismo tiempo una especificación completa del contenido de su aspecto pasivo. Al determinar quién tiene derecho a qué queda también determinado, tratándose de estos derechos, quién tiene qué deber. Esto tiene una consecuencia de extraordinaria importancia. Los derechos de primera generación pueden ser concebidos como naturales, porque para especificar su contenido tanto activo como pasivo es suficiente

\footnotetext{
${ }^{11}$ Christodoulidis, "The Inertia of Institutional Imagination”, 381. Por eso Simone Weil creía que era necesaria una 'declaración de deberes de la humanidad'. Véase Weil, "Estudio para una declaración".

${ }^{12}$ Declaración de Independencia Norteamericana (1776).
} 
atender a la posición del individuo aislado. Pero los derechos sociales son radicalmente diversos en este sentido. La especificación del contenido de su aspecto activo no constituye una especificación completa del contenido de su aspecto pasivo. Ella no incluye información ni sobre quién es el sujeto obligado ni sobre cuál es el contenido de su obligación. La respuesta a esta pregunta sólo es posible una vez que los individuos viven en comunidad, de modo que es posible, por ejemplo, cargar a todos de acuerdo a sus capacidades (e.g. a través de un sistema impositivo progresivo) con la obligación de satisfacer las necesidades cubiertas por los derechos sociales. En la medida en que los derechos cumplen la función de justificar la existencia del estado (es decir, en la medida en que ellos necesitan ser caracterizados con prescindencia de cualquier forma de asociación entre seres humanos), ellos sólo pueden ser los derechos naturales, derechos de esos que hoy llamamos de 'primera' generación ${ }^{13}$.

\footnotetext{
${ }^{13}$ Sólo esta nota para llamar la atención sobre la supuesta distinción entre derechos de 'primera' y 'segunda' generación sobre la base de la distinción derechos negativos/positivos, y ello sólo para decir que esta distinción es teóricamente irrelevante. Ello en virtud de que una obligación es positiva o negativa según su descripción, y habitualmente encontramos que para cada derecho hay descripciones alternativas disponibles, porque las acciones de cumplimiento de un deber, así como las acciones en general, pueden recibir múltiples descripciones verdaderas (véase Atria, "Legalismo, política y derechos", en M Alegre, A do Amaral et al: Los Derechos Fundamentales (Buenos Aires: Editores del Puerto, 2003), 119-121). Dada esta constatación, es usual concluir que no hay distinción conceptual entre los derechos de ambas generaciones, una conclusión que se utiliza polémicamente contra pensadores neoliberales que afirman no sólo la diferencia, sino la importancia sólo de los derechos de primera generación (como lo hace, por ejemplo, Kelley, A Life of One's Own, 23-29). Dudo de la utilidad de una estrategia argumentativa que consiste en encontrar algún derecho de primera generación y declararlo 'positivo' para después poder decir, sobre la base de ese contraejemplo, que eso refuta 'en sus propios términos' la tesis de la distinción entre derechos negativos y derechos positivos (como lo hace, e.g. Elster, "Right to work"). Usualmente el contraejemplo escogido es el derecho al debido proceso (e.g. Nickel, "Right to employment"). Esto último contiene en todo caso un error cuya clarificación es provechosa para la distinción que estoy defendiendo. Comenzamos recordando que la distinción relevante no es la distinción entre derechos positivos y derechos negativos, sino la distinción, introducida en esta sección, entre derechos que pueden ser concebidos como naturales porque su justificación normativa no hace referencia a la comunidad y derechos que no pueden ser así concebidos. Respecto del contraejemplo del debido proceso, todo lo que es necesario es distinguir entre el contenido de un derecho en abstracto y el contenido que a la luz de las circunstancias el derecho adquiere. El derecho en abstracto es el de libertad negativa: nadie puede interferir con mis acciones lícitas. Cuando por convención creamos el Leviathan, lo que hacemos es crear un agente más poderoso que cada uno de nosotros, con lo que seremos capaces de salir de la condición natural de la humanidad. Este agente puede interferir con nuestra libertad de maneras en que antes los individuos separadamente no podían, y por lo tanto los modos en que él puede afectar mi libertad negativa están sujetos a ciertas garantías: ahí el debido proceso. No es correcto decir que yo tengo derecho al debido proceso. Lo que tengo es derecho a que el estado no interfiera con mi vida (propiedad, libertad etc) sino en circunstancias especiales (cuando la interferencia es necesaria para salvaguardar los derechos de otros) y en todo caso de un modo adecuado. 'Debido proceso' es el nombre que damos al modo de la interferencia (o su antecedente) cuando es adecuado. En general, es posible decir: la vida en asociación hace posible nuevas formas de violación
} 
Ahora podemos ver cómo todo calza: los derechos hicieron su irrupción histórica como justificando la revolución, como proponiendo las bases justificatorias de una nueva forma de asociación entre seres humanos. Por eso la visión liberal era unilateral, y por eso no era formalista (al menos no en sentido peyorativo): no era que otras necesidades fueran menos importantes, sino que ellas no estaban cubiertas por derechos que pudieran ser concebidos como naturales.

4. Pero desde luego, a medida que la revolución empieza a desaparecer del horizonte y que la normalidad empieza a negar (como la normalidad se define por hacer ${ }^{14}$ ) el recuerdo del momento fundacional, la distinción entre la forma de un derecho (que justifica la preferencia por los bienes que podían ser concebidos como protegidos por derechos naturales) y su sustancia (que precisamente impugna esa diferencia) empieza a perder su contenido emancipador y comienza a ser percibida como opresiva. En efecto, para quienes no tenían acceso a un cierto nivel de bienestar material los derechos aparecían sólo en su aspecto pasivo: como imponiendo deberes de respeto a la libertad de otros. Pero no aparecían en su aspecto activo, porque no hay espacio para la libertad cuando uno está sujeto a la necesidad de la reproducción de la vida ${ }^{15}$. Esta idea aparece claramente en La Internacional:

La ley nos burla y el Estado oprime y sangra al productor.

Nos da derechos irrisorios, no hay deberes del señor.

Basta ya de tutela odiosa, que la igualdad ley ha de ser,

no más deberes sin derechos, ningún derecho sin deber ${ }^{16}$.

\footnotetext{
de los viejos derechos, por lo que en concreto cómo han de respetarse esos derechos depende del contexto. El derecho al debido proceso es simplemente una contextualización del derecho a la libertad negativa, y por eso no es una objeción a la tesis principal (esto ha sido escrito en respuesta a una objeción del profesor Marcelo Alegre).

${ }^{14}$ Por eso Jefferson quería mantener artificialmente el recuerdo del momento fundacional, disponiendo que la constitución debía ser revisada cada diez y nueve años: Jefferson, Writings, 1401-2.

${ }^{15}$ Este es un tema central en la obra de Hannah Arendt, que enfatiza la idea de que la libertad sólo es posible en público porque el espacio privado es el espacio de la reproducción de la vida, de la necesidad. Véase Arendt, Human Condition, 36-7, 68-73, etc [43-45, 102-103, etc].

${ }^{16} \mathrm{La}$ frase es de Marx, y aparece en el Capítulo $4^{\circ}$ del panfleto The International Workingmen's Association. Its Establishment, Organisation, Political and Social Activity, and Growth (1869): "El Congreso cree que es el deber de un hombre reclamar los derechos del hombre y del ciudadano, no solo para sí mismo, sino para cada hombre que cumple su deber. No más derechos sin deberes, no más deberes sin derechos".
} 
A la unilateralidad y formalismo de la doctrina liberal de los derechos los socialistas (al menos algunos de ellos) respondieron formulando sus propias demandas en el mismo lenguaje ${ }^{17}$. Parte importante de lo que quiero sostener en este artículo se relaciona con el modo en que debemos interpretar este paso, por lo que quiero detenerme aquí un momento. Más adelante sostendré que la idea comunitaria a la que el socialismo apela no es traducible a la lengua de los derechos. Quiero entonces explicar por qué, a mi juicio, ese fue el lenguaje elegido para formular ese ideal ${ }^{18}$. Para eso, sin embargo, deberemos hacer un pequeño desvío conceptual.

5. ¿Qué diferencia hay entre decir 'dar (o hacer o no hacer) $x$ a $w$ es bueno (justo etc)' y decir ' $w$ tiene derecho a $x$ '? Espero que sea evidente que ésta es una pregunta fundamental para que tenga sentido empezar a hablar de derechos ${ }^{19}$. No se trata, desde luego, de que las dos cuestiones sean distintas en el sentido de que la respuesta a una no tenga impacto alguno en la respuesta a la otra. No, la cuestión no es de independencia o autonomía sino de diferenciación. Si tiene sentido decir que $w$ tiene derecho a $x$, no puede ser que con eso sólo estemos diciendo que es bueno que se dé, haga o no haga $x$ a $w$. Cuando decimos que el comprador tiene derecho a que el vendedor le entregue la cosa ciertamente estamos diciendo mucho más que al decir que es lícito para el vendedor entregar la cosa.

Quizás podamos aprender algo de la noción de derecho mirando al modo de operación de un derecho subjetivo en el sentido jurídico. Para el derecho, lo crucial para que podamos hablar de derecho subjetivo es la posición en la que se encuentra una persona con potestad para decidir si la obligación de otro será o no coactivamente exigida ${ }^{20}$. No se trata de que el vendedor

\footnotetext{
${ }^{17}$ Probablemente aquí lo más adecuado sería empezar a hablar de 'socialdemócratas', porque en cuestiones como estas la tradición socialista empieza a fraccionarse (véase la discusión entre lo que Campbell, The Left and Rights, 2-12 llama 'reformistas' y 'revolucionarios'). Con esta advertencia, sin embargo, seguiré utilizando la etiqueta 'socialismo'.

${ }^{18}$ Esto no es ofrecido como una tesis historiográfica (hasta donde yo sé la historia de los derechos sociales está todavía esperando ser escrita), sino una interpretación de esa tradición hecha desde nuestro tiempo, en particular una que pretende explicar por qué la idea de derechos sociales, en la particular forma juridificada en que hoy es comúnmente defendida, es tan dominante entre los pensadores de izquierda (o, como se les llama ahora, 'progresistas').

${ }^{19}$ Villey, por ejemplo, ha mostrado que la idea moderna de derecho subjetivo supone la distinción entre 'la cualidad moral que corresponde a una persona para tener o hacer algo justamente' (Villey sigue aquí la definición de Grotius: $c f r$. Villey, “Orígenes de la noción”, 26), y ‘lo justo, el objeto de la justicia' (ibid 34). ${ }^{20}$ cfr. Kelsen, Teoría Pura, 147-8. Uso 'potestad' en el sentido de Hohfeld, Conceptos Jurídicos, 67-80.
} 
no tenga obligación de entregar la cosa, porque todos sabemos que esa obligación nace con el contrato y no con la demanda del comprador. Pero sabemos que parte de lo que queremos decir al decir que el comprador tiene un derecho subjetivo es que el comprador tiene una potestad en el sentido hohfeldiano, es decir, tiene un poder normativo para modificar la situación del otro: la manifestación de voluntad del comprador es condición necesaria (aunque desde luego no suficiente) para que el derecho exija coactivamente al vendedor el cumplimiento de su obligación. No puede decirse lo mismo respecto de otras obligaciones que uno puede tener de acuerdo a un sistema jurídico: la exigibilidad de mi deber de pagar impuestos, o evitar matar a otro, no están mediadas por la declaración de voluntad de ninguna persona determinada ${ }^{21}$.

La razón por la cual la obligación es mediada por una declaración de voluntad de un individuo (el titular del derecho) es que la única (o la principal y dominante) razón por la cual el derecho crea esa obligación es atender a un interés del acreedor ${ }^{22}$. Por eso no diríamos que, en países con procedimientos penales acusatorios y principio de oportunidad, el fiscal tiene un derecho subjetivo a que los ciudadanos no comentan delitos. Aun cuando la sanción penal es mediada por la acción del fiscal (en el sentido de que si el fiscal no inicia el procedimiento no habrá sanción), la razón por la cual se produce esa mediación no es reducible al interés del sujeto que ocupa el cargo de fiscal.

Si el razonamiento hasta ahora es correcto, estamos en posición de concluir que para que en sentido jurídico podamos hablar de un derecho subjetivo es necesario que una persona,

(i) tenga una obligación

(ii) cuya exigibilidad está jurídicamente mediada por la declaración de voluntad de otra;

$\mathrm{y}$

(iii) que sea reconocida o creada por el derecho en atención al interés de esa otra.

\footnotetext{
${ }^{21}$ cfr. Kelsen, Teoría Pura, 141. Este es el argumento kelseniano para negar afirmar la prioridad de la noción de deber sobre la de derecho: hay deberes que no son correlativos a derechos, porque hay deberes que en cuanto a su exigibilidad no están mediados por la declaración de voluntad de otra persona ( $c f r$. supra, nota 9).

${ }^{22}$ Con lo cual pareciera que estoy defendiendo una teoría 'ecléctica' en cuanto al fundamento del derecho subjetivo, ecléctica entre voluntad e interés. Pero no quiero pronunciarme explícitamente sobre esto, que ha de quedar pendiente para otra ocasión.
} 
¿Qué nos dice esto respecto del concepto de derecho tal como aparece, e.g. en la expresión 'derechos humanos'? Es evidente que aquí lo que es crucial desde el punto de vista jurídico (i.e. la posibilidad de demandar coactivamente el cumplimiento de la obligación correlativa) deviene irrelevante ${ }^{23}$. Sin embargo, es razonable pensar que el concepto jurídico y el moral de derecho subjetivo son fundamentalmente análogos, por lo que una característica fundamental del concepto jurídico debería corresponder a alguna característica fundamental del concepto moral ${ }^{24}$. En otras palabras: es razonable pensar que las características institucionales que adopta el derecho subjetivo en sentido jurídico son un reflejo de algo importante acerca de los derechos morales que el derecho pretende proteger, y es eso a lo que tenemos que atender ahora.

6. Quiero defender la tesis (nada novedosa, por lo demás) que tener derecho (moral) a x significa que, en principio ${ }^{25}$, es posible pronunciarse sobre la justicia de dar, hacer o no hacer $x$ a $w$ sin necesidad de evaluar el impacto que dar, hacer o no hacer $x$ a $w$ tendrá en otros aspectos moralmente valiosos. Decir que $w$ tiene derecho a que $v$ cumpla su promesa es decir que en principio es justo que $v$ haga lo que prometió hacer, conclusión a la que podemos llegar sin necesidad de considerar el impacto que la acción de cumplir su promesa tendrá en otras cuestiones moralmente valiosas. Si esto es correcto, la noción de 'derechos' en algún sentido implica recortar la situación de dos personas, el acreedor y el deudor, y separarla del resto de las consideraciones morales válidas,

\footnotetext{
${ }^{23}$ Véase Dabin, Derecho Subjetivo, 121-128.

${ }^{24}$ Formulo este argumento con cierta cautela, para no ser malentendido. La cuestión recuerda el problema, largamente debatido en la tradición analítica del positivismo jurídico, de si el 'concepto' de obligación jurídica era el mismo que el 'concepto' de obligación moral. No estoy afirmando que derechos (morales y jurídicos) sean la misma cosa, que ambos se encuentran en los códigos inmutables del derecho natural, ni nada parecido. Sólo estoy suponiendo que hay entre ambos 'notables semejanzas que bastan para mostrar que su vocabulario común no es accidental' (Hart, Concept of Law, 172 [214], con referencia al concepto de obligación). Por eso, una explicación del concepto que muestra que lo que es jurídicamente crucial corresponde a alguna característica que es moralmente crucial es, ceteris paribus, una mejor explicación que otra que no muestra eso. Nada más debe leerse en el argumento del texto principal.

25 'En principio', porque el argumento no supone que es una verdad conceptual que los derechos no sean derrotables. Sobre el problema de la derrotabilidad en general, véase Atria, "Las circunstancias de la derrotabilidad", en 45 Revista de Ciencias Sociales (2000): 437-467, e idem, On Law and Legal Reasoning (Oxford: Hart Publishers, 2002), caps. 1 y 5.
} 
de modo que sea posible determinar la justicia de la acción del deudor sin mirar más que a la específica relación existente entre deudor y acreedor, porque lo moralmente dominante es la manera en que (dentro de ciertos límites) el interés del acreedor ha de ser servido por el deudor. Por eso es perfectamente concebible que uno tenga derecho moral a hacer algo moralmente lamentable ${ }^{26}$.

Lo anterior nos permite desde luego conectar la noción de derecho subjetivo en sentido jurídico con la noción moral correspondiente. Hemos visto que jurídicamente lo crucial para poder hablar de derecho subjetivo es que la exigibilidad de la obligación del deudor esté mediada por la voluntad del acreedor. Ahora sabemos que esa característica del concepto jurídico de derecho es reflejo de una característica moral análoga: que el derecho (en sentido moral) significa recortar el rango de consideraciones morales aplicables a la determinación de la justicia de una acción, porque dado el contexto en el que el derecho aparece lo dominante es cómo es servido el interés del acreedor. Jurídicamente esta nota se manifiesta a través de la exigibilidad mediada. El derecho entiende que el que mejor conoce sus intereses es el propio interesado (salvo en casos especiales, para los cuales el derecho cuenta con otros medios como las reglas sobre incapacidad y representación, para los casos en que una persona no sabe proteger sus intereses, o sobre auto-contratación, cuando está a cargo de intereses propios y ajenos, o sobre (e.g.) insinuación, cuando están en juego los intereses de otros).

Nótese que las observaciones anteriores sobre el concepto de derecho subjetivo son bastante parcas desde el punto de vista de las cuestiones substantivas que esta noción plantea. En particular, esas consideraciones son silenciosas respecto de problemas como los siguientes: (i) el peso de los derechos frente a las consideraciones morales que ellos hacen irrelevante; (ii) la correcta manera de describir el razonamiento moral conforme a

\footnotetext{
${ }^{26}$ Véase Waldron, “A right to do wrong?”. Hay por eso algo de paradojal en la noción de derecho moral, porque tener derecho a $x$ significa entonces que es justo dar, hacer o no hacer $x$ aun cuando tomando en cuenta otras consideraciones sería mejor no dar, hacer o no hacer $x$ (esta es la objeción estándar de utilitaristas de actos contra utilitaristas de reglas, expresada de modo categórico en Smart, "Extreme and restricted"). Por eso nótese que los contextos en los cuales el concepto moral de derecho es aplicable de modo más adecuado son contextos altamente institucionalizados, como el contexto ya mencionado de la promesa. La cuestión ha sido discutida de modo inmejorable por Rawls, "Two concepts".
} 
derechos, si se trata de lo que Raz ha denominado razones excluyentes ${ }^{27} \mathrm{O}$ simplemente de razones especialmente fuertes de primer orden; y (iii) las condiciones de derrotabilidad de los derechos ${ }^{28}$. En principio, uno pensaría que la respuesta a este y otros problemas no puede ser zanjada con argumentos sobre la correcta comprensión del concepto de derechos y requiere una teoría substantiva, moral o política.

Pero lo anterior sí nos muestra qué se sigue del hecho de que una teoría moral entienda a los derechos como el concepto central: sabemos que esa teoría sustantiva afirma que las consideraciones morales no cubiertas por derechos sólo son moralmente relevantes para determinar la justicia de una acción o situación cuando los derechos involucrados ya han sido satisfechos. Al declarar a los derechos como el concepto moral fundamental, los intereses que esos derechos protegen son doblemente priorizados: en tanto conceptos fundamentales (i.e. esos son los intereses más importantes) $\mathrm{y}$ en tanto derechos (porque en principio no compiten con intereses no protegidos por derechos). Así, por ejemplo, en la teoría de la justicia de J Rawls la libertad es doblemente priorizada: por un lado, la libertad es un derecho, por lo que para saber cuál es la extensión de la libertad sólo es necesario mirar a la situación del acreedor (o titular) de ese derecho y los deudores (cada uno tiene derecho a 'la libertad básica más extendida compatible con una libertad similar para los otros' ${ }^{29}$ ) y está adicionalmente ordenada lexicográficamente con el segundo principio. Por eso la tesis de Dworkin, que los derechos son 'cartas de triunfo' ${ }^{30}$ no es puramente estipulativa: ella refleja una de las características básicas de la idea misma de 'derechos'.

Que de la sola consideración del concepto de derechos subjetivos no se sigan muchas consecuencias substantivas no significa, por tanto, que una teoría sustantiva que afirme que los derechos son fundamentales en el sentido de que son el fundamento de la legitimidad de la asociación política sea igualmente agnóstica. Esto es importante porque el hecho de que al menos

\footnotetext{
${ }^{27}$ En Raz, Practical Reason and Norms, 37-48 [39-54].

${ }^{28}$ Véase supra n. 25.

${ }^{29}$ Rawls, Theory of Justice, $\S 11$.

${ }^{30}$ Dworkin, "Rights as Trumps".
} 
ciertos derechos son fundamentales es algo que puede, en el estado actual de la discusión, darse por establecido. Si no fuera por otra razón, porque así lo afirman todas nuestras constituciones. Por eso lo que resulta interesante es estudiar el problema de cuáles son las consecuencias sustantivas de utilizar el aparato conceptual de los derechos, y eso es lo que quiero hacer en lo que sigue.

7. Aclarados como lo hemos hecho los conceptos, ahora podemos entender la especial importancia que los derechos suelen reclamar. Ella radica en que los derechos en principio sólo conocen como límites otros derechos: 'el ejercicio de los derechos naturales no tiene otros límites que aquellos que aseguran a los demás miembros de la sociedad el goce de los mismos derechos', dice la declaración francesa (art. 4). Por consiguiente, las demandas socialistas sólo podían reverberar en el discurso liberal si eran manifestadas como derechos, de modo que pudiera decirse que el conflicto entre esas demandas era un conflicto de derecho contra derecho (permitido) y no de derecho contra utilidad general o aspiración comunitaria (no permitido).

En efecto, si las demandas socialistas se manifestaban en el lenguaje de la aspiración comunitaria, la respuesta liberal habría indefectiblemente de ser que en tanto objetivos agregativos esas aspiraciones comunitarias no podían competir con los derechos. Al presentarlas como derechos, el liberalismo se veía enfrentado a un dilema, porque debía optar entre (1) mantener su adhesión prioritaria a los derechos de 'primera' generación, declarándolos más importantes que las otras necesidades, e implicando así que lo importante era, por ejemplo, gozar de libertad 'formal', aunque esa libertad fuera substancialmente vacía (el rico y el pobre eran libres de dormir bajo los puentes de París) o (2) aceptar que las condiciones para el ejercicio legítimo y substancialmente significativo de las libertades fueran también cubiertas por derechos con al menos el mismo título que ellas ${ }^{31}$.

Un ejemplo de un ataque al liberalismo que sigue el modelo anterior, formulado precisamente desde una perspectiva socialista, es el de G A Cohen

\footnotetext{
${ }^{31}$ Aquí sólo un ejemplo de un argumento que hoy por hoy se ha hecho estándar: 'si los derechos fundamentales apuntan a lo que es fundamentalmente importante para el bienestar humano, no podemos excluir de su área los recursos materiales. En particular se ha dicho a menudo que, sin un mínimo de bienestar material, los derechos civiles y políticos tienen escaso valor y relevancia para los seres humanos' (Jones, Rights, 147).
} 
contra R Nozick:

Desde luego, Nozick nos quiere hacer creer, que la propiedad de uno mismo [self-ownership] que él favorece es más que meramente formal. En el capítulo III de Anarchy, State and Utopia él sostiene que cada persona debe ser libre de vivir su propia vida, un desideratum que es supuestamente asegurado por los derechos que constituyen la propiedad sobre uno mismo [self-ownership] nozickeana. Pero Nozick también cree que el proletario más abyecto llamémoslo $Z$ - que debe elegir entre vender su fuerza de trabajo a un capitalista o morir, goza de los derechos relevantes ${ }^{32}$.

Para decir lo primer Nozick necesita entender la propiedad sobre uno mismo en el sentido de control sobre la propia vida (noción que, según él está vinculada a la idea de llevar una vida 'con sentido' ${ }^{33}$ ). Pero $Z$ no tiene control, sobre su vida en este sentido. Para decir que $Z$ es dueño de sí mismo Nozick necesita recurrir a una noción más débil de dominio sobre uno mismo, un concepto meramente formal de propiedad sobre uno mismo. Éste es el dilema del liberalismo que la idea de derechos sociales pretendía explotar: o los liberales afirman la prioridad de los derechos de primera generación, declarando a $Z$ libre en el sentido relevante, y demostrando que no les preocupa la libertad real de todos (sino que sólo quieren decir por libertad 'la libertad de los dueños de la propiedad privada de hacer lo que quieran con su propiedad ${ }^{34}$ ) o adoptan un concepto substantivo de libertad, uno que niegue la prioridad de la forma sobre la substancia.

El contraste entre las ideas originalmente defendidas por Nozick en Anarchy, State and Utopia y la crítica de Cohen es interesante para nuestros efectos, porque la de Nozick es precisamente una filosofía política basada en derechos. Eso la hace una filosofía política formalista ${ }^{35}$; la crítica de Cohen se basa en la arbitrariedad de usar la noción de derechos (y su complemento, aunque él no usa esa expresión, la noción de relación de derecho privado) como concepto central de la filosofía política.

Estoy conciente de que el párrafo anterior debe haber resultado oscuro a muchos lectores, por lo que intentaré aclararlo. Cohen discute la siguiente tesis, que (justamente) imputa a Nozick (sigo la numeración de Cohen):

\footnotetext{
${ }^{32}$ Cohen, Self-ownership, 100.

${ }^{33}$ Nozick, Anarchy, 50 [60].

${ }^{34}$ Cohen, Self-ownership, 90. Recuérdese los versos de La Internacional citados supra, $\$ 4$.

${ }^{35}$ En el sentido no peyorativo de Weinrib, Idea of Private Law, 22-55.
} 
(8) Si $Z$ es forzado a hacer $A$ o $B$, y $A$ es lo único que sería razonable que haga, y $Z$ hace $\mathrm{A}$ por esa razón, entonces $Z$ es forzado a hacer $A^{36}$.

La discusión de fondo es: el trabajador que se ve ante la alternativa de trabajar (recibiendo el salario de mercado) o vivir en la miseria, y que por eso elige trabajar, ¿es forzado a trabajar? Según (8), pareciera que lo es, porque la opción entre trabajar y padecer miseria no es razonable. Pero, por supuesto, si se concediera que el trabajador es forzado a trabajar no podría decirse que bajo el capitalismo los trabajadores son libres, y no podría decirse que la sociedad capitalista es una sociedad libre.

Como Nozick quiere poder decir estas últimas dos cosas, él tiene que mostrar por qué, a pesar de que acepta (8), el proletario que se ve enfrentado a la opción de vender su poder de trabajo o enfrentar la miseria es, en el sentido relevante, libre. Para esto, Nozick sostiene que las restricciones que otros ponen a las opciones que una persona tiene abiertas no disminuyen la libertad de éste, ni la voluntariedad de sus acciones, en la medida en que el otro tenga derecho a ponerlas:

La cuestión de si las acciones de una persona son voluntarias depende de qué es lo que limita sus alternativas. Si las limitan los hechos de la naturaleza, las acciones son voluntarias (puedo caminar voluntariamente a un lugar al cual preferiría volar por mí mismo). Las acciones de otras personas limitan las oportunidades abiertas para uno. Para decidir si esto hace a las acciones resultantes de uno voluntarias es necesario determinar si los otros tenían derecho a actuar como lo hicieron ${ }^{37}$.

La explicación de por qué 'un pensador extremadamente agudo's8 como Nozick sostendría una tesis tan implausible es que la teoría de Nozick es una teoría de la justicia que podríamos llamar de derecho privado. El derecho privado, como ha mostrado elegantemente $\mathrm{E}$ Weinrib $^{39}$, se basa en la idea de que lo que una persona debe a otra es determinado no por consideraciones externas (i.e. externas a la relación entre ambas partes) de justicia sino por la especial configuración de la relación entre las partes. Por eso Nozick cree que no puede saberse si la limitación de las opciones que $Z$ sufre es una merma de su libertad sin saber si quien las crea (esas limitaciones) ha actuado con derecho a hacerlo o no. Desde el punto de vista de una consideración

\footnotetext{
${ }^{36}$ Cohen, Self-ownership, 35.

${ }^{37}$ Nozick, Anarchy, 262.

${ }^{38}$ Cohen, Self-ownership, 36.

${ }^{39}$ Weinrib, Idea of Private Law, 8-16.
} 
externa (a la relación), que es la óptica asumida por Cohen, es evidente que para responder la pregunta sobre si $Z$, en el caso, es libre o no debemos saber (a) cuán significativa es la opción que le resta a $Z$ y (b) en qué consiste la libertad (cuestión que viene dada por una teoría de la libertad que es en principio externa a la relación entre $A$ y $B$ ). Estas dos cuestiones son declaradas irrelevantes en la medida en que la teoría de la justicia es construida sobre el supuesto básico, como lo hace Nozick, de que la justicia de la situación en la que se encuentra una persona, o la justicia de una acción, depende de las características de la relación que une a las partes involucradas.

Nótese el formato de la cuestión: los derechos, en Nozick, son naturales en el sentido de que no son artificialmente creados por el Estado ni por la asociación política (las partes tienen derechos en el estado de naturaleza ${ }^{40}$ ), y lo que es justo se determina mirando solamente a la manera en que los derechos que las partes tienen afectan una determinada acción o situación. Esto lleva naturalmente a una teoría de la justicia distributiva que es fundamentalmente justicia conmutativa (una teoría basada en los títulos, más que una teoría basada en patrones, como dice el propio Nozick ${ }^{41}$ ).

8. Ahora podemos, entonces, entender la aparición de la 'segunda' generación de derechos frente a la primera: quien acepta la primera lo hace como un vacío gesto formal, a menos que acepte también la segunda. Y por eso hay algún sentido en que es correcto decir, con N Bobbio, que haber logrado la incorporación de los derechos de segunda generación en un pié de igualdad con los de la primera puede ser considerado

una de las conquistas más clamorosas [...] de los movimientos socialistas que han sido identificados al menos hasta ahora con la izquierda ${ }^{42}$.

La idea aquí no es que a los liberales les importan sólo las libertades civiles y políticas y que a los socialistas les importan sólo los derechos sociales $^{43}$. Liberales y socialistas defienden los bienes detrás de ambas

\footnotetext{
${ }^{40}$ Sobre el estado de naturaleza, véase Nozick, Anarchy, 3-25 [17-38]

${ }^{41}$ Weinrib, Idea of Private Law, 150-160.

42 Bobbio, Derecha e Izquierda, 151; para Peces-Barba, los derechos sociales son 'una aportación socialista original al acervo de los derechos humanos' (en Peces-Barba, Derecho y Derechos Fundamentales, 413); por su parte, Carl Schmitt, Teoría de la Constitución, 175, denomina a los derechos sociales 'derechos y pretensiones socialistas (o más suavemente: sociales)' (énfasis agregado). cfr. también Waldron, "Nonsense upon stilts?" 158.

${ }^{43} \mathrm{O}$ ambos, como solía sostenerlo la propaganda soviética. Véase e.g. .
} 
generaciones de derechos ${ }^{44}$, pero la diferencia estriba en la razón por las que ellos son importantes en cada tradición. En la tradición liberal los derechos se fundan en el auto interés (porque ellos no dependen de sino anteceden a la comunidad) o, para expresarlo de una manera más elegante, en lo que Rawls llama el 'mutuo desinterés' 45 . El liberalismo, en su variante 'progresista', acogió la idea de derechos sociales, pero para fundarlos debe recurrir a una concepción más amplia que lo común de auto-interés, un enlightened selfinterest. Por eso, los derechos sociales en clave liberal son concebidos como una especie de seguro que cada agente toma para precaverse de la posibilidad de encontrarse descubierto y necesitado.

Steven Holmes ha mostrado, de hecho, que los autores liberales clásicos efectivamente reconocían la existencia de ciertos 'derechos de bienestar' [welfare rights]. Pero precisamente como ellos manejaban una noción 'natural' de derechos, i.e. derechos existentes en el estado de naturaleza (derechos en cuya justificación normativa el hecho de vivir en comunidad no aparece), esos derechos de bienestar sólo podían tener como límite máximo ese estado: es irracional acceder a un pacto constitutivo si en virtud del pacto el sujeto quedará peor de cómo estaba en el estado de naturaleza ${ }^{46}$. Si uno no tuviera un derecho de bienestar, un derecho a un nivel de vida apenas superior a la vida 'solitaria, pobre, desagradable, bruta y breve' de que habla Hobbes ${ }^{47}$, entonces los demás ciudadanos no podrían exigirle respeto a la autoridad. Por eso los derechos de bienestar que Holmes encuentra en la tradición liberal no son derechos sociales en el sentido socialdemócrata, sino derechos a un mínimo ${ }^{48}$. Lo que los ofende no es la

\footnotetext{
${ }^{44}$ Como dice el mismo Bobbio: ‘¿Qué doctrina política no tiene que ver en mayor o menor medida con la igualdad?' Bobbio, Derecha e Izquierda, 141. Véase adicionalmente infra, n. 48.

${ }^{45}$ Rawls, Theory of Justice, 13-14 [31]. Véase Atria y Michelon, "Is Rawls egalitarian? A critique of the difference principle" (inédito, disponible por correo).

${ }^{46}$ Hobbes, Leviathan, 21 [178].

${ }^{47}$ ibid. Cap. 13 [103]

${ }^{48}$ Holmes invoca a autores liberales clásicos como Smith, Montesquieu, Locke y Hobbes, entre otros. Para Hobbes las leyes del estado debían proveer a la mantención de quienes 'por accidente evitable, resultan incapaces para mantenerse a sí mismos' (Hobbes, Leviathan, Cap. 30 [284]; cfr. Holmes, "Liberal Guilt", 88); Smith destacaba la necesidad de que el gobierno se hiciera cargo de "la ayuda a los pobres' (Smith, Wealth of Nations, V.i.d.5 [641]; cfr. Holmes, "Liberal Guilt", 90); para Montesquieu, se trata de dar 'a los obreros en necesidad momentánea [...] un socorro rápido, tanto para prevenir el sufrimiento del pueblo, o para evitar una rebelión' (Montesquieu, Espíritu de las Leyes, Cap. 23 \$29; cfr. Holmes, "Liberal Guilt", 95); Locke, por ultimo, reconoce a cada uno un título sobre la riqueza de los demás, "para mantenerlos alejados de la necesidad extrema, en tanto carezcan de medios para subsistir de otra manera' (Locke, Two Treatises, i §42 [85]; (cfr. Holmes, "Liberal Guilt", 86).
} 
desigualdad, sino la pobreza ${ }^{49}$.

En la tradición socialista, los derechos sociales son una manifestación de un forma superior de comunidad, una en que (e.g.) cada uno contribuye de acuerdo a sus capacidades, y recibe de acuerdo a sus necesidades. Esta es precisamente la idea discernible en el análisis ofrecido por T H Marshall ${ }^{50}$. Los derechos sociales constituyen una manera más amplia, más completa de concebir la ciudadanía, y como la ciudadanía es la pertenencia a una comunidad política, los derechos sociales de los que nos habla Marshall son la consecuencia de una nueva forma de concebir la asociación comunitaria. Ahora la sola pertenencia a la comunidad política es suficiente para fundar esos derechos. La diferencia entre la ciudadanía liberal (i.e. derechos civiles y políticos, en términos de Marshall) y la socialista es que mientras la primera es una forma de comunidad que se caracteriza porque sus miembros "no tienen interés en los intereses de otros ${ }^{\prime}{ }_{1}$, la segunda es una forma de comunidad en que cada uno de sus miembros tienen un interés en el bienestar del otro, un interés que se extiende, como lo expresara el slogan del National Health Service británico, 'from craddle to grave' (desde la cuna hasta la tumba).

La distinción entre (la eliminación de la) pobreza y desigualdad nos da la clave para distinguir entre una concepción que llamaré 'liberal' y una 'socialista' de los derechos sociales. Como sostiene Marshall,

La reducción de las desigualdades de clase es también la finalidad de los derechos sociales, pero ha adquirido un nuevo sentido. Ya no es solamente un intento de disminuir los desagrados obvios de la miseria. Ahora se presenta como acción tendiente a modificar todo el patrón de desigualdad social. Ya no se satisface con levantar el nivel del suelo en el subterráneo del

\footnotetext{
${ }^{49}$ Por supuesto, estas maneras diversas de entender los derechos sociales tienen consecuencias institucionales también diversas. Un estado de bienestar liberal se caracteriza por la focalización, lo más precisa posible, de los programas sociales a quienes están por debajo de la línea de la pobreza, y su finalidad se limita a levantarlos hasta esa línea; un estado de bienestar socialista (socialdemócrata), por el contrario, recurre de modo más típico a programas universales y no focalizados (en los estudios comparados de estados de bienestar es común encontrar referencia a una tercera categoría: el estado corporativo de bienestar, pero aquí no necesitamos considerarla). Un buen ejemplo del estado liberal de bienestar es Estados Unidos, mientras países como los escandinavos son los casos ejemplares de estados socialdemócratas de bienestar (Alemania es el ejemplo tradicional del estado corporativo de bienestar). La formulación canónica de estos diferentes 'mundos' del capitalismo de bienestar está en EspingAndersen, Three Worlds of Welfare Capitalism; véase también Goodin, Headley, Muffels y Dirven, Real Worlds of Welfare Capitalism.

${ }^{50}$ Marshall, Citizenship and Social Class, 8-17 [22-36].

${ }^{51}$ Rawls, Theory of Justice, 13 [31].
} 
edificio, dejando los pisos superiores como estaban. Ha comenzado a remodelar el edificio completo, y puede incluso convertir un rascacielos en un bungalow ${ }^{52}$.

De lo que se trata ahora, entonces, es de examinar cómo estas dos concepciones pueden expresarse a través del razonamiento jurídico.

9. Antes de eso, sin embargo, es necesario enfatizar que en sus principios la noción de 'derechos (naturales)' no era parasitaria de la noción de derecho (subjetivo). No era, en otras palabras, reducible $n i$ a la tesis de que todos los seres humanos en tanto tales gozan de esos derechos en el sentido jurídico del término $n i$ a la tesis de que ellos deberían tener, conforme al derecho del Estado respectivo, esos derechos subjetivos.

En vez de hacer alusión a los derechos subjetivos que los individuos tienen o deben tener la noción política de derechos (humanos, naturales, etc) afirmaba que ciertos bienes (libertad, igualdad ante la ley, educación, protección de la salud, etc) eran especialmente importantes en el sentido fundacional identificado más arriba. Es perfectamente coherente utilizar el lenguaje de los derechos como lenguaje político y no jurídico. El sentido político de la expresión ' $w$ tiene derecho (humano, natural, etc) a $x$ ' puede perfectamente ser 'un Estado es ilegítimo, y su autoridad se basa en su sola fuerza, si no asegura a $w$ el goce de $x^{5_{3}}$. Pero como hay muchas maneras a través de las cuales $x$ puede ser garantizado, es perfectamente posible que $w$ goce de $x$ sin que la forma jurídica a través del cual se le garantice sea un derecho subjetivo a $x$.

Pero esta última idea nada en contra del Zeitgeist. Hoy es común encontrarse con la idea de que o los derechos humanos no significan nada, o significan que los seres humanos por el hecho de ser tales de hecho gozan, o (en su versión más plausible) deberían gozar de los derechos humanos como derechos subjetivos reconocidos por el sistema jurídico ${ }^{54}$. En otras palabras, hoy parece haber un consenso cada vez más extendido sobre la idea de que los derechos humanos son parasitarios respecto de los derechos subjetivos jurídicos, en tanto se definen por su relación con éstos. Esta idea, evidente como puede hoy parecernos, es relativamente nueva. De hecho, por

\footnotetext{
${ }^{52}$ Marshall, Citizenship and Social Class, 28 [52].

${ }^{53}$ Véase Atria, "Legalismo, política y derechos", supra n. 13.

${ }^{54}$ Para una formulación bastante explícita de esta idea, véase infra, texto que acompaña n. 87.
} 
ejemplo, la Declaración de los Derechos del Hombre y del Ciudadano no fue ni pretendió ser una ley, sino una declaración sin efectos jurídicos propios ${ }^{55}$. En efecto, ¿cómo podría alguien tener derecho subjetivo a la seguridad? Lo mismo puede decirse de la declaración norteamericana, e incluso de la declaración universal de 1948. La declaración universal tenía por finalidad promover 'una concepción común' de ellos que permitiera evitar 'actos ultrajantes para la conciencia de la humanidad', de modo que, viviendo en 'un mundo librados del temor y la miseria', los hombres no se vieran 'compelidos al supremo recurso de la rebelión contra la tiranía y la opresión's6. Por eso lo que los pueblos del mundo hicieron fue declarar esos derechos, declaración que debe entenderse como un esfuerzo por hacer del mundo un lugar en que las atrocidades que habían ocurrido recientemente fueran menos probables; el mundo es distinto desde que entendemos que él (todo el mundo) es habitado por seres que tienen esos derechos. La declaración es un acto performativo, cuyo sentido es cambiar el mundo al declararlo cambiado.

Hoy, sin embargo, todo esto es rápidamente descartado como retórica política, lenguaje 'metafórico' o 'figurativo' ${ }^{57}$, 'meras' declaraciones de principio, obligaciones 'programáticas' que a nada obligan, a menos que los derechos declarados impliquen al menos la exigencia de conceder a su titular un derecho subjetivo dotado de todas las características propias de los derechos subjetivos, especialmente exigibilidad. En este contexto, hay un sentido importante en que el conflicto político, especialmente en Latinoamérica (y también en Europa del este ${ }^{58}$ ) se ha desplazado desde las calles o parlamentos hacia las cortes.

10. El desplazamiento al que me refiero no es simplemente un cambio de locus institucional, aunque nadie puede negar que la importancia política de los tribunales ordinarios y constitucionales ha aumentado de modo considerable en, digamos, los últimos 20 años. El problema no es (o no es sólo) que hoy sean tribunales los que decidan cuestiones que antes estábamos acostumbrados a creer que debían ser decididas por asambleas representativas.

\footnotetext{
${ }^{55}$ La importancia de este hecho es una cuestión que me fuera destacada por Michel Troper.

${ }^{56}$ Declaración Universal de Derechos Humanos (Naciones Unidas, 1948), preámbulo.

${ }^{57}$ cfr. Peces-Barba, Derecho y Derechos Fundamentales, 415-416.

${ }^{58}$ Celebrando este desarrollo véase Schwartz, Struggle for Constitutional Justice.
} 
Esto de hecho ha ocurrido y es importante, pero adicionalmente se ha producido un cambio de valoración del derecho y su relación con la política. Hoy el derecho es visto como el medium de la acción política. Por supuesto, el derecho siempre estuvo relacionado con la política, al menos en el sentido de que el derecho era el resultado de la política. Pero en algún sentido importante la política gozaba de cierta prioridad frente al derecho.

Para entender esta prioridad, es útil considerar el momento en que ella fue explícitamente formulada en términos de teoría del derecho ${ }^{59}$. Me refiero al surgimiento del positivismo jurídico en la Inglaterra de fines del siglo XVII y principios del siglo XVIII. Lo que caracterizaba a ese positivismo no era la pretensión de determinar las condiciones de conocimiento científico del derecho (como en Kelsen ${ }^{60}$ ), ni proveer un análisis del 'concepto' de derecho (como en Hart ${ }^{61}$ )sino el objetivo político de afirmar la autonomía del derecho como instrumento político. En términos de $\mathrm{N}$ Bobbio, se trataba de un positivismo ideológico o ético ${ }^{62}$.

En efecto, el positivismo jurídico nació junto al estado nación afirmando que el derecho es artificial, y que en consecuencia lo que los juristas llamaban la 'razón artificial' del derecho no era sino un disfraz para dar mayor respetabilidad a sus preferencias políticas (habitualmente conservadoras). Siendo el derecho artificial, una manifestación de la voluntad del soberano, entonces los juristas y los jueces están sometidos a él. Los juristas y los jueces modernos ya no pueden entender la ley como la habían entendido los

\footnotetext{
${ }^{59} c f r$. Atria, "La ironía del positivismo jurídico", de próxima aparición en DOXA (2005).

${ }^{60}$ cfr. Atria, “¿Es posible una 'Teoría Pura' de la argumentación jurídica?”, de próxima aparición en Squella (ed), ¿Qué Queda de la Teoría Pura del Derecho? (Valparaíso: Edeval).

${ }^{61}$ cfr. Atria, supra n. 59.

${ }^{62}$ Bobbio, Positivismo Jurídico, 233-235; Bobbio cree sin embargo que el positivismo ético (en su versión 'moderada') afirma el valor del orden. Sin embargo esto, así como la versión 'extrema' del positivismo ético identificada por Bobbio, parece también 'propia más de los adversarios que de los defensores del positivismo jurídico' (Bobbio, Positivismo Jurídico, 233). El positivismo ético no tiene por qué afirmar que todo derecho por ser derecho tiene valor, ni siquiera 'moderadamente' (véase Atria, "Bobbio y el positivismo ético", de próxima aparición en Anuario de Filosofía Jurídica y Social (Valparaíso, 2005)). Es posible tener una teoría positivista ética (como es, creo, la mejor interpretación de la tradición positivista) que enfatiza el valor del autogobierno democrático y que defiende la estricta sujeción a la ley del juez (dado un modo de producción del derecho que refleja el autogobierno) como la única manera en que ese valor puede ser servido. En este sentido, véase Campbell, Ethical Positivism, y Campbell y Goldsworthy (eds), Judicial Power.
} 
medievales, es decir como derivaciones de la ley natural que en consecuencia podían ser derivaciones correctas o incorrectas, sino como manifestaciones de voluntad del soberano que en tanto tales no podían ser correctas o incorrectas: para el juez y el jurista debían ser consideradas dogmas. El positivismo es la manifestación jurídica de la idea política moderna de que los gobiernos (y el derecho) son instituidos artificialmente por los hombres, que en consecuencia pueden, como dijeron los revolucionarios norteamericanos en 1776 ,

reformarlos o abolirlos, e instituir un nuevo gobierno y organizar sus poderes en la forma que a su juicio garantice mejor su libertad y seguridad ${ }^{63}$.

El positivismo era, en este sentido (al igual que el movimiento codificador), un movimiento para asegurar la sujeción a la ley de los 'sinister interests' de 'Judge \& Co' ${ }^{64}$, afirmando la prioridad de la política (el derecho como voluntad, no como razón) sobre la razón artificial del derecho ${ }^{65}$.

Hoy, sin embargo, la relación entre derecho y política se ha invertido y se nos invita a celebrar la sujeción de la política al derecho. A esta visión, que concibe al derecho como lo que estructura, limita y ordena el conflicto político, la denominaré 'legalismo' ${ }^{66}$. El legalismo ya no concibe al derecho como el 'gran ocultador de la opresión' ${ }^{67}$, sino como el medio a través del cual la comunidad se constituye a sí misma. Ahora el derecho expresa 'el pueblo que queremos ser y la comunidad que aspiramos a tener' ${ }^{68}$. Liberales y republicanos celebran el potencial emancipador del derecho, aunque uno

\footnotetext{
${ }^{63}$ Declaración de Independencia Norteamericana (1776).

${ }^{64}$ Bentham, Rationale of Judicial Evidence, 199-210. Van Caenegem ha enfatizado que 'históricamente, la codificación fue un arma utilizada en contra de la judicatura' (van Caenegem, Judges, 152).

${ }^{65}$ Por supuesto, esta prioridad creaba una tensión con la noción de estado de derecho, en especial con la noción de estado material de derecho (en la medida en que la idea de estado formal de derecho miraba a la configuración positiva de la potestad legislativa como la mejor garantía, mientras el estado material considera esa garantía insuficiente e introduce criterios materiales de legitimación). Véase en general, sobre este tema, Böckenförde, "Origen y cambio"; véase también Atria, "Legislation and adjudication", de próxima aparición en ICON - International Journal of Constitutional Law.

${ }^{66}$ cfr. Shklar, Legalism, 111 [125]. Véase adicionalmente Atria, "Legalismo, política y derechos", supra $\mathrm{n} .13$

${ }^{67}$ Christodoulidis, Law and Reflexive Politics.

${ }^{68}$ Dworkin, Law's Empire, 413.
} 
podría haber esperado algo distinto ${ }^{69}$. Incluso entre las posturas más explícitamente radicales, es a través de la subversión de los significados jurídicos, la detección del contraprincipio que yace, indefectiblemente, escondido bajo el principio, que será posible volver a luchar por los viejos ideales de la izquierda ${ }^{70}$. En la práctica política, especialmente en varios de los países latinoamericanos (Argentina y Chile entre ellos ${ }^{71}$ ) la idea de utilizar foros judiciales para luchar por el progreso social y político se ha hecho más y más corriente, y esos foros consecuencialmente más y más importantes ${ }^{72}$.

El supuesto básico de esta aceptación generalizada del derecho como el medio de expresión del conflicto político es que el derecho es neutral, es decir, que el discurso jurídico permite la expresión sin distorsiones de las pretensiones políticas. La idea ha sido explícitamente defendida por Zagrebelsky: el derecho es 'dúctil' '73. Lo curioso de esto es que navega en contra de una importante idea, sostenida por autores tan diversos como Pashukanis, Hayek y Marx: que el derecho no es neutral, que en algún sentido importante la forma del derecho está vinculada a los mismos arreglos políticos y económicos que la izquierda detesta ${ }^{74}$. Marx expresaba esta idea en un famoso pasaje de Sobre la cuestión judia:

los llamados derechos humanos, los droits de l'homme, a diferencia de los droits du citoyen, no son otra cosa que los derechos del miembro de la sociedad civil, es decir, los derechos del hombre egoísta, del hombre que vive al margen del hombre y la comunidad [...]. El derecho humano de la libertad no descansa sobre la unión del hombre con el hombre, sino que se basa, por el contrario, en la separación entre los hombres ${ }^{75}$.

\footnotetext{
${ }^{69}$ Habermas destaca aprobatoriamente el hecho de que 'no deja de ser interesante que el republicanismo, como quizás hubiese cabido esperar de su inspiración demócrata-radical, no se convierta en abogado del judicial self-restraint' (Habermas, Facticidad y Validez, 351).

${ }^{70}$ Unger, Critical Legal Studies; cfr. también Unger, What Should Legal Analysis Become, y en general (aunque crítico de la crítica crítica) Altman, Critical Legal Studies.

${ }^{71}$ Por Argentina, véase la crónica de Böhmer, "La corte de los '80"; por Chile, véase Atria, "Revisión Judicial: el sindrome de la víctima insatisfecha", en 79 Estudios Públicos (2000): 347-402.

${ }^{72}$ En Chile y en latinoamérica, influyentes programas de 'acciones de interés público' y un uso reiterado de acciones de amparo o (como son denominadas en Chile) protección de derechos constitucionales por parte de ONGs han convertido a las cortes en árbitros de conflictos que hace un tiempo no podría haber sido entendido sino como conflictos políticos por excelencia. Al respecto, véase González, "Evolución y perspectivas". Véase adicionalmente Correa Sutil, "Cenicienta se queda en la fiesta", y Atria, "La hora del derecho. Los 'derechos humanos' entre el derecho y la política”, en 91 Estudios Públicos (2003): 45-90. ${ }^{73}$ Zagrebelski, Derecho Dúctil.

${ }^{74}$ Véase Pashukanis, Law and Marxism; Hayek, Rules and Order. La explicación del sentido en que Hayek y Pashukanis coinciden en identificar a la forma del derecho (no sólo a su contenido) con el capitalismo de mercado está en Bankowski, Living Lawfully, 80-89; cfr. también Waldron, “Karl Marx’s 'On the jewish question'“, 126.

${ }^{75}$ Marx, Critique of the Gotha program, 478.
} 
11. Dentro del derecho y de las constituciones, el locus natural que sirve de sucedáneo para el conflicto político es el conjunto de derechos reconocidos por las constituciones modernas y/o los tratados internacionales. De hecho, si Zagrebelsky está en lo correcto y el derecho es completamente dúctil, las demandas de liberales y socialistas debieran poder reaparecer en el discurso jurídico sin sufrir tergiversaciones, como interpretaciones en competencia de enunciados jurídicos vagos como los que aparecen, por ejemplo, en lo que se denomina la 'parte dogmática' de las constituciones.

No cabe duda de que en una buena medida eso es así. Como ha señalado Jeremy Waldron ${ }^{76}$ el conflicto jurídico tiende a reflejar el conflicto político. Esto es mucho más evidente cuando se trata de cuestiones jurídicas cuyas consecuencias políticas son especialmente directas, como suele ser el caso tratándose de cuestiones relacionadas con la interpretación y protección de los derechos fundamentales. En otras palabras, la idea crítica de que el derecho es política es correcta en cuanto implica que el conflicto político se manifiesta en el conflicto jurídico, que éste no es autónomo de aquél.

Sin embargo, para que el derecho sea neutral, es decir, para que a través de él se pueda manifestar el conflicto político sin distorsiones de traducción, no es suficiente que el discurso jurídico carezca de autonomía respecto del discurso político. Se requiere adicionalmente que el derecho sea completamente dúctil, en el sentido de que cualquier reclamo político pueda ser manifestado a través de él sin necesidad de distorsionarlo, es decir, sin necesidad de presentarlo de un modo distinto a como en efecto es ${ }^{77}$.

$Y$ es ésta la condición que el derecho no puede cumplir. Una manera de explicar por qué el derecho no puede cumplir esta condición es considerando la discusión sobre la relevancia jurídica de los derechos sociales, porque tratándose de derechos sociales el sentido jurídico del substantivo no es neutral respecto de las dos maneras ya distinguidas ${ }^{78}$ de entender el significado político del adjetivo.

\footnotetext{
${ }^{76}$ En Waldron, Law and Disagreement, 221-231 y passim.

${ }^{77} \mathrm{Al}$ menos tratándose de posiciones políticas que en términos de Rawls, Political Liberalism, 48-58 [67-71] sean razonables.

${ }^{78}$ Supra, $\$ 8$.
} 
12. Si el argumento hasta ahora es plausible, una de las formas en las que la confrontación política entre liberalismo y socialismo reaparece dentro del discurso jurídico es como una confrontación entre derechos civiles y políticos y derechos sociales y la importancia relativa de cada grupo. Parece que en el derecho nuestra época simplemente ha encontrado un nuevo lenguaje en el cual resolver los conflictos de siempre. Ahora quiero mostrar que esta apariencia es engañosa, porque el derecho no permite expresar sin distorsión esos conflictos: el derecho es dúctil, pero no completamente dúctil. Ni siquiera suficientemente dúctil.

En abstracto, el argumento es relativamente simple: hemos visto que el concepto de derecho subjetivo hace referencia a la idea de que lo que es justo dar, hacer o no hacer al titular del derecho puede determinarse con independencia de consideraciones substantivas de índole general. Por eso los derechos triunfan (al menos en principio) sobre consideraciones de utilidad general o aspiraciones comunitarias. El mayor bienestar social o la aspiración comunitaria no pueden constituir una razón que triunfe sobre un derecho. Esto es lo que 'tener derecho a...' significa en el juego de lenguaje del derecho. El comprador demandante no necesita probar, para obtener en el juicio, que la sociedad como un todo estará mejor si su demanda es acogida, y el vendedor demandado no puede oponer una 'excepción de bienestar general' para excusarse del cumplimiento ${ }^{79}$.

Los fines colectivos (o comunitarios) que justifican los derechos sociales, en consecuencia, no podrán vencer a los derechos individuales si no están expresados en el lenguaje de los derechos. En tanto aquellos sean 'sólo' fines agregativos éstos siempre saldrán triunfadores. Como hemos

\footnotetext{
${ }^{79}$ Nada obsta, desde luego, que se reforme el Código Civil y que se cree una excepción de bienestar general.

El argumento sólo implica que, en la medida en que eso fuera el caso, lo que el vendedor tendría dejaría de ser reconocido como un derecho subjetivo (la cuestión es un poco más compleja, sin embargo). Que el vendedor tenga una excepción de utilidad general es estrictamente compatible con que el comprador tenga un derecho a la entrega de la cosa, porque tal excepción podría cumplir la función de la cláusula 'en principio' discutida más arriba (supra n. 25). Pero si el comprador necesitara probar que su demanda va en el bien general, o si el vendedor pudiera excusarse de cumplir probando solamente que en las circunstancias, es conveniente socialmente que él no cumpla (y no sólo para evitar, parafraseando a Nozick, Anarchy, 30n [42n], 'horrores jurídicos catastróficos'), entonces no podríamos decir que en realidad tiene un derecho).
} 
visto, esa es una de las razones por la que los derechos sociales fueron precisamente presentados como 'derechos'. Pero por supuesto, una vez que esas ideas comunitarias son expresadas como 'derechos' la idea comunitaria en la que descansan es negada y la demanda es entendida como una de individuos en contra de la comunidad.

El argumento a seguir tiene como corolario que hay un sentido importante en el cual la expresión 'derechos sociales' es una contradicción, es tan contradictoria como 'soltero-casado'. A pesar de esto, mucho esfuerzo e inteligencia se ha gastado en ofrecer una noción de derechos sociales que sea razonable. Sin embargo, persiste siempre una tensión entre lo que depende del contenido del material jurídico positivo (i.e. positivado, puesto) y lo que depende del modo de operación de las prácticas institucionalizadas que llamamos 'jurídicas'; una tensión, en otras palabras, entre mirar a la sustancia contingente del derecho puesto o a su forma necesaria de operación (necesaria, i.e. en tanto jurídica) para explicar la especial (devaluada) posición que ocupan los derechos sociales frente a los derechos de primera generación en los sistemas jurídicos occidentales.

Quiero ahora mostrar algunas instancias del fenómeno indicado. Para eso, comenzaremos mostrando cómo la tensión entre la sustancia del derecho y su forma de operación aparece al analizar los modos de operación de los derechos sociales y los bienes que protegen; luego el examen será dirigido a dos propuestas aparentemente contradictorias sobre cómo deberíamos proteger esos bienes, para terminar con un caso en que el discurso jurídico hace estrictamente imposible un significado político ${ }^{80}$.

13. Comenzamos considerando un aspecto de la discusión sobre el estatus normativo de los derechos sociales en la Constitución Española. Como se sabe, la mayoría de los bienes que habitualmente se denominan derechos sociales son agrupados por esta constitución en su capítulo $3^{\circ}$, al que luego se le niega protección judicial. Ante esta situación, autores como L. Prieto se preguntan por qué los denominados 'principios rectores de la política económica y social'

\footnotetext{
${ }^{80}$ Sostendré que lo que he denominado la 'concepción socialista' de los derechos sociales no puede sobrevivir a la juridificación del concepto, la que entonces impone sobre el mismo un significado liberal. Esa concepción es entonces la que ahora discutiremos. Por eso, en lo que sigue utilizaré la expresión 'derechos sociales' para referirme sólo a la concepción socialista ya identificada.
} 
del capítulo III de la Constitución Española aparecen en ese texto constitucional 'jurídicamente devaluados' ${ }^{81}$, en particular si esa devaluación 'responde en verdad a alguna exigencia técnica o representa más bien el fruto de una decisión política'82 (nótese como Prieto ha formulado con toda precisión la tensión identificada más arriba). Como Prieto encuentra en otras partes de la Constitución Española derechos que muestran las posibles notas características de los derechos sociales, pero que están dotados de exigibilidad judicial, inicialmente concluye que si los principios rectores se hallan jurídicamente devaluados

no es principalmente porque sean derechos sociales, es decir, no es porque reúnan algunas de las características propias de esa categoría de derechos, sino que obedece más bien a la voluntad constituyente ${ }^{83}$.

No obstante esta conclusión, Prieto luego nos informa de que la jurisprudencia del Tribunal Constitucional español ha reconocido valor normativo a los principios rectores, aunque uno limitado, porque 'la concreta operatividad de los mismos no resulta siempre uniforme y generalmente depende de la presencia de otras disposiciones relevantes para el caso' ${ }^{84}$. Cuando la pregunta que Prieto intenta responder es por qué el reconocimiento del 'valor normativo' de los principios rectores es limitado de este modo, la explicación que nos ofrece no descansa ya en una 'decisión política' de la 'voluntad constituyente' contenida en el capítulo III, porque 'aun cuando' esa decisión cambiara, permitiendo la protección judicial de esos derechos, es probable que los tribunales no pudiesen llegar mucho más lejos de donde ha llegado la doctrina del tribunal Constitucional [...]. Por la propia naturaleza de la actividad jurisdiccional, de los posibles efectos de sus sentencias y de la fuerza ejecutiva de las mismas, cabe suponer que mientras no se arbitre una articulación detallada de los distintos principios, el otorgamiento de amparo judicial mostraría una virtualidad bastante limitada ante el vacío jurídico de normas secundarias o de organización ${ }^{85}$.

Aquí vemos cómo Prieto se mueve entre los dos extremos del dilema que estamos examinando: si la razón por la cual los derechos sociales están jurídicamente devaluados es 'una declaración expresa de la voluntad

\footnotetext{
${ }^{81}$ Prieto, Estudios, 190.

${ }^{82}$ ibid, 187.

${ }^{83}$ ibid, 190 (destacado agregado).

${ }^{84}$ ibid, 196.

${ }^{85}$ ibid, 197-98 (destacado agregado).
} 
constituyente' pareciera que basta cambiar el contenido de esa voluntad para revaluarlos. Pero si la devaluación se debe a la naturaleza de los mecanismos jurídicos de exigibilidad, entonces hemos chocado con los límites de la ductibilidad del derecho. En el primer caso, podemos mantener el derecho como medium y dirigir nuestros esfuerzos a cambiar el contenido del derecho, a reemplazar la decisión constituyente por una decisión de contenido contrario; en el segundo caso, intentar cambiar la decisión constituyente sería inútil del modo más irónico, porque 'aun cuando' esa decisión fuera modificada nos encontraremos con que la protección de los derechos sociales no puede ser equiparable a la que gozan los derechos civiles y políticos. Y éste es un 'no puede' que atestigua las limitaciones del lenguaje jurídico como lenguaje institucionalizado: las instituciones son dúctiles, pero no completamente.

Para mostrar que el derecho no puede proteger los derechos sociales como puede proteger los derechos civiles y políticos no es suficiente, sin embargo, un argumento abstracto sobre la naturaleza institucional del derecho y el contenido político de sus conceptos: es necesario ver cómo fallan los intentos de torcer la forma del derecho para adecuarlo al contenido buscado. 14. Para apreciar esto puede ser interesante comentar algunas ideas sobre derechos sociales, aparentemente opuestas, que tres autores argentinos han defendido recientemente. Me refiero, por un lado, a Los Derechos Sociales como Derechos Exigibles de V. Abramovich y C. Courtis, y 'La pobreza, la ley y la constitución' de C. Rosenkrantz. Es interesante destacar que, a pesar de lo alejados que se encuentran entre sí los argumentos de cada uno de ellos (Abramovich y Courtis alegando que los derechos sociales deben ser tratados como los derechos civiles y políticos en cuanto a su exigibilidad y protección jurisdiccional, y Rosenkrantz, por su parte, alegando que debemos considerar seriamente la posibilidad de eliminar los derechos sociales de nuestros catálogos constitucionales) ambos comparten la idea de que los derechos sólo son plenamente reconocidos cuando son jurisdiccionalmente protegibles ${ }^{86}$. En realidad sus argumentos, a pesar de lo disímiles que parecen, son perfectamente complementarios: muestran cuáles son las consecuencias que se siguen del modo en que el derecho entiende los derechos. Al ser ambas

${ }^{86}$ Véanse los textos que acompañan a las notas 87 (por Abramovich y Courtis) y 97-98 (por Rosenkrantz). 
posiciones insuficientes, como intentaré mostrar, ellas conjuntamente muestran los límites de la ductibilidad del derecho.

En su alegato por la exigibilidad de los derechos sociales, Abramovich y Courtis parten de una posición que puede parecer extraña, porque parecen preferir el agua sucia de la bañera antes que al bebé:

aunque un Estado cumpla habitualmente con la satisfacción de determinadas necesidades o intereses tutelados por el derecho social [...] ningún observador podría afirmar que los beneficiados por la conducta estatal gozan de ese derecho como derecho subjetivo hasta tanto verificar si la población se encuentra en realidad en condiciones de demandar judicialmente la prestación del Estado ante un eventual incumplimiento ${ }^{87}$.

Aquí Abramovich y Courtis parecen querer decir que para que un derecho social se encuentre plenamente reconocido no es suficiente (ni necesario) que el Estado satisfaga la necesidad a la que se refiere, porque ese reconocimiento no se alcanzará 'hasta superar los obstáculos que impiden su adecuada justiciabilidad' ${ }^{\prime 8}$. Pero políticamente, desde luego, parece preferible preferir la sustancia a la forma.

A pesar de lo políticamente insensata que pueda parecer, creo que esta posición de Abramovich y Courtis es jurídicamente impecable, porque jurídicamente la forma triunfa sobre la sustancia: si los derechos sociales son derechos, es decir, si deben ser entendidos conforme a la técnica de los derechos subjetivos, entonces ellos deben poder ser reclamables. Para el abogado es irrelevante que el vendedor entregue la cosa, lo que importa es que el comprador tenga una acción para exigir la entrega si el vendedor incumple. Que el derecho no reconozca una acción a una determinada pretensión quiere decir, como hemos visto ${ }^{89}$, que esa pretensión no constituye un derecho subjetivo en el sentido propio del término. Ubi remedium, ibi jus: cualquier abogado entendería inmediatamente el sentido en el que el acreedor de una obligatio naturalis no tiene realmente un derecho subjetivo a la prestación precisamente porque no puede demandarla judicialmente. Como los derechos sociales son reconocidos como derechos (i.e. aparecen como tales en los catálogos de prácticamente todas las constituciones occidentales), la conclusión forzosa es que ellos son tan accionables como los derechos civiles

\footnotetext{
${ }^{87}$ Abramovich y Courtis, Derechos Sociales, 37.

88 ibid 37.

${ }^{89}$ Véase supra, §5.
} 
y políticos. Estrictamente, todos ellos son igualmente accionables, porque su accionabilidad les viene dada por el hecho de que sean reconocidos (o configurados) por el sistema jurídico como derechos. Por así decirlo, lo que los hace accionables es que sean derechos, con prescindencia de si son o no sociales.

Pero lo que un argumento inteligente da el derecho lo quita. Abramovich y Courtis entienden que los derechos sociales no pueden ser completamente exigibles, porque en una medida importante ellos dependen de sistemas que el juez no puede, por el tipo de cargo que ocupa, crear $^{90}$. En esos casos, por supuesto, la exigibilidad de los derechos sociales es severamente limitada: No cabe duda de que la implementación de derechos económicos, sociales y culturales depende en parte de actividades de planificación, previsión presupuestaria y puesta en marcha que por naturaleza corresponden a los poderes políticos siendo limitados los casos en que el poder judicial puede llevar a cabo la tarea de suplir la inactividad de aquellos ${ }^{91}$.

Nótese la referencia, de nuevo, a lo que por naturaleza es el caso: lo que queda excluido de la protección por la 'naturaleza' del derecho es precisamente la idea central de los derechos sociales en su comprensión socialista: que ellos configuran una forma diferente de comunidad, una en que la comunidad como un todo se preocupa del bienestar de cada uno de sus miembros. Sólo una noción de este tipo completa la caracterización del contenido pasivo de esos 'derechos'.

Habiendo excluido esta dimensión de los derechos sociales, los autores creen poder rescatar algo todavía: la idea de que algunos aspectos de esos derechos son exigibles. Pero sorprendentemente (o, quizás: predeciblemente), cuando ellos proceden a determinar de modo preciso cuáles son estos aspectos, lo que aparece no son ni derechos sociales, ni las necesidades que los derechos sociales tienden a satisfacer: la principal dimensión de exigibilidad de los derechos sociales, la que 'queda siempre abierta', nos dicen los autores, es

\footnotetext{
${ }^{90}$ Porque, como hemos visto, la caracterización de su aspecto activo no caracteriza completamente su aspecto pasivo (véase supra, §3). Aquí no basta saber que $w$ tiene derecho a $x$ para poder concluir quién tiene qué obligación. Quizás a la vista del caso particular el juez puede llegar a la conclusión de que sería bueno o justo o correcto que se proveyera al demandante del servicio que reclama, pero de eso no se sigue respuesta a la pregunta de quién ha de ser el proveedor.

${ }^{91}$ Abramovich y Courtis, Derechos Sociales, 44 (énfasis agregado).
} 
la posibilidad de plantear judicialmente la violación de obligaciones del Estado por asegurar discriminatoriamente el derecho ${ }^{92}$.

Pero al hablar de esto no estamos hablando de la exigibilidad de los derechos sociales, sino del viejo derecho a la igualdad formal, el derecho a la igualdad que aparece en la declaración francesa de 1789 y la americana de 1776: la igualdad de ricos y pobres para atender una mediocre escuela pública, o postular a una minúscula vivienda pública, o concurrir a un desmedrado consultorio de salud estatal. 'Mediocre', 'minúscula' o 'desmedrado' no porque la provisión de servicios públicos sea desigualitaria (en nuestros países todas las escuelas, viviendas y consultorios públicos son mediocres, minúsculas o desmedradas en comparación con sus equivalentes privados). Lo que Abramovich y Courtis dejan 'siempre abierto' no implica estándar alguno de evaluación entre los sistemas públicos y privados ${ }^{93}$.

Pero aun cuando es posible ir más allá de lo que 'queda siempre abierto', y cuando la violación a un derecho social puede ser directamente invocada ante un tribunal, es necesario que ella sea 'reformulada [...] en términos de violación individualizada y concreta, en lugar de en forma genérica' ${ }^{94}$. De este modo el derecho social a la protección de la salud, que originalmente consistía en que se garantizara un nivel de atención de salud a todos (porque una comunidad en la que todos nos preocupamos por los otros es una comunidad más decente que otra en la que cada uno persigue su bienestar individual y el resto lo hace la mano invisible), se convierte en un derecho individual alegado por el demandante de que se obligue al Estado a dar una determinada prestación de salud, sin que las necesidades de los otros puedan ser relevantes (las necesidades de los otros aparecen ante el

\footnotetext{
92 ibid, 43.

${ }^{93}$ De hecho, tampoco implica un estándar significativo entre un servicio público determinado, porque como Marshall señalaba, la provisión progresiva de un cierto beneficio puede implicar desigualdades formales. Véase Marshall, Citizenship and Social Class, 35 [62]. Nótese aquí el dilema: o el 'aseguramiento igualitario del servicio' impide la mejora progresiva por parcialidades (porque una mejora de algunas escuelas, que no beneficia a los usuarios de otras, sería contraria al derecho al 'aseguramiento igualitario del servicio' de éstos), por lo que deberíamos concluir que sólo la reforma completa del servicio es compatible con los derechos sociales (lo que significa que los espacios políticos de reforma son prácticamente inexistentes), o no lo impide (y entonces deberíamos concluir que un derecho al 'aseguramiento igualitario', que no impide ni distinciones entre la calidad de los servicios públicos y privados ni distinciones dentro de un servicio público tiene en realidad una utilidad bastante limitada). ${ }^{94}$ Abramovich y Courtis, Derechos Sociales (el destacado es agregado).
} 
juez como no distribuidas, es decir, como objetivos de política o aspiraciones comunitarias, y por eso los derechos las triunfan). Lo que llega al tribunal no es un derecho social, no puede ser un derecho social, sino una demanda privada, que expresa ya no la idea de una forma superior de comunidad sino la negación de ésta: la pretensión del demandante de que su interés sea atendido, aun a costa del interés de los demás.

Abramovich y Courtis creen que ellos pueden aprovecharse de la ductilidad del derecho y apropiarse del término 'derecho subjetivo' sin por eso hacerse cargo del 'contexto político-ideológico que culminó en la articulación técnica de esa noción' ${ }^{95}$. Pero si el argumento hasta ahora es correcto, los conceptos muerden de vuelta de modo perverso: no se trata de que Abramovich y Courtis hayan adaptado la noción individualista de derecho subjetivo a sus finalidades sociales, sino que sus finalidades sociales han sido secuestradas por el concepto que han elegido. Para cambiar el sentido político de un concepto jurídico no basta querer cambiarlo ${ }^{96}$.

15. C. Rosenkrantz, por su parte, llega a la conclusión precisamente opuesta: como el derecho no puede redimir la promesa de los derechos sociales, éstos en tanto derechos jurídicos están condenados a mantenerse como una promesa incumplida, devaluando de paso las otras promesas que el derecho hace, en particular la promesa de defender los derechos civiles y políticos: 'la existencia de derechos constitucionales que no son ejecutables mella la credibilidad de toda la constitución' ${ }^{\prime 97}$. Como los derechos civiles y políticos nos interesan a todos, entonces tenemos razones para cuidar la credibilidad de la constitución, y para eso debemos remover los derechos sociales de nuestras constituciones.

Rosenkrantz, agudamente, percibe que el problema está en la manera (contingente a su juicio) en que los derechos se entienden en la cultura jurídica argentina:

$\mathrm{Si}$, como sucede en nuestro caso, su cultura jurídica asocia íntimamente el derecho y la coerción,

\footnotetext{
${ }^{95} \mathrm{ibid}, 58$.

${ }^{96}$ Los autores se percatan de algo parecido que ocurrió cuando se intentó utilizar el derecho privado para proteger derechos no patrimoniales 'como la vida, la libertad de conciencia, la libertad religiosa o los llamados derechos personalísimos'. El derecho sólo pudo otorgarles protección judicial comodificándolos, traduciendo 'su afectación a términos de rendimiento económico' (ibid, 51n51). Sin embargo, no se dan cuenta de los efectos devastadores que para la idea original de derechos sociales (o derechos no patrimoniales, como en este caso) esta necesidad de 'traducción' implica.

${ }^{97}$ Rosenkrantz, "La pobreza, la ley y la constitución”, 247.
} 
la presencia de derechos no-ejecutables seguramente depreciará el valor de la constitución como una norma guiadora de nuestro comportamiento social ${ }^{98}$.

Supongo que nos mantenemos fieles a Rosenkrantz si corregimos esta afirmación ligera aunque significativamente. Lo determinante no es la cultura jurídica del país del caso, porque para el derecho no hay derechos subjetivos sin acción (en otras palabras: en la 'cultura jurídica' occidental, la idea jurídica de derecho subjetivo está siempre y necesariamente, no contingentemente, vinculada a la acción para exigir el cumplimiento coactivo ${ }^{99}$ ). El problema al que apunta Rosenkrantz es la existencia contingente de una cultura política en la cual los enunciados políticos sobre derechos son entendidos como si fueran parasitarios de enunciados jurídicos sobre derechos.

Este énfasis en la distinción de lo jurídico y lo político puede parecer un purismo pasado de moda, pero en realidad la cuestión es importante, como lo demuestra precisamente el caso de los derechos sociales. Los derechos sociales no pueden ser exigibles como derechos subjetivos. Para hacer de los derechos sociales derechos jurídicamente exigibles es necesario des-socializarlos, como hemos visto que Abramovich y Courtis efectivamente hacen.

Rosenkrantz por supuesto no alega que por eso no debamos preocuparnos de obtener bienes como salud, educación, vivienda y trabajo para todos: sólo alega que esos bienes no pueden estar protegidos constitucionalmente por derechos sociales, a menos que estemos dispuestos a poner en peligro todo el sistema de derechos fundamentales.

El significado político de aceptar la tesis de Rosenkrantz, sin embargo, es profundamente conservador. Una constitución como la que defiende Rosenkrantz, en la que los derechos sociales no son reconocidos, sería sin duda el paradigma de una constitución de derecha. Ni la constitución chilena de Pinochet llegó tan lejos como el argumento de Rosenkrantz sugeriría ${ }^{100}$. Y esta posición extremadamente conservadora no se sigue de argumentaciones

\footnotetext{
${ }^{98}$ ibid, 247-8.

${ }^{99}$ Véase supra, $\S 5$.

${ }^{100} \mathrm{Al}$ hacerle presente esta objeción al profesor Rosenkrantz, él se defendió diciendo que no temía ser acusado de derechista porque él no era derechista. Pero esto hace su posición más insostenible: el derechismo de su posición no se basa en un argumento derechista, sino en consideraciones sobre el derecho y los derechos. ¿Qué mejor demostración podría uno pedir de que el lenguaje del derecho no es neutral políticamente? Si uno va a defender una tesis derechista, ¿no sería razonable hacerlo porque uno es derechista?
} 
conservadoras de Rosenkrantz, sino de una premisa que hoy parece evidente: que la constitución es 'la última palabra en la determinación de la acción política' ${ }^{101}$, y que adicionalmente la constitución debe ser entendida como un texto jurídico cualitativamente igual a las leyes y otras normas ${ }^{102}$. Paradojalmente, el argumento de Rosenkrantz lleva a la misma conclusión que el esfuerzo de Abramovich y Courtis: si el discurso político es parasitario del discurso jurídico, si el derecho es el medio a través del cual la política se manifiesta, si el lenguaje del derecho es el lenguaje de la política, entonces la promesa de los derechos sociales debe ser ignorada.

El texto de Rosenkrantz es especialmente importante porque muestra de modo evidente el efecto político del discurso jurídico: Como está visto, la colonización de la política por el derecho hace ininteligible la pretensión socialista de un nuevo modo de comunidad, originalmente expresado en el lenguaje político (no jurídico) de los derechos. Al mismo tiempo, impone una concepción liberal de los derechos. Pero la colonización de la política por el derecho se presenta a sí misma como neutral, en el sentido de que es agnóstica entre liberalismo y socialismo (y otros, desde luego). Precisamente para mantener ese agnosticismo, Rosenkrantz presenta lo que a su juicio es su argumento más fuerte en contra de la constitucionalización de los derechos sociales, una objeción que él denomina 'epistémica' y que se basa en el hecho de que hay desacuerdo sobre los derechos sociales.

Dado ese desacuerdo, insistir en la constitucionalización de los derechos sociales excluye a quienes no están de acuerdo con nuestra visión de ellos: ¿Cómo hará [usted] para sentirse integrado con el resto de nosotros en una comunidad política cuando sus opiniones en temas tan importantes que todavía no han sido políticamente saldados no pueden producir ningún resultado político en razón de que nuestra visión sobre los mismos temas ha sido privilegiada mediante su inclusión en la constitución? ${ }^{103}$

Pero para quienes creen en los ideales comunitarios que justifican los derechos sociales, la situación es precisamente ésta: sus opiniones políticas

\footnotetext{
${ }^{101}$ Rosenkrantz, "La pobreza, la ley y la constitución”, 248.

${ }^{102}$ No he discutido aquí la cuestión del significado de esta re-conceptualización de la constitución. Algo he dicho, sin embargo, en Atria, "Legalismo y reflexividad: la contraloría como modelo", en J Pallavicini y R Herrera (eds): La Contraloría General de la República y el Estado de Derecho (Santiago: Contraloría General de la República, 2002), y en "La constitución y la contingencia de lo político", de próxima aparición en DOXA (2004).

${ }^{103}$ Rosenkrantz, "La pobreza, la ley y la constitución”, 250.
} 
sobre la comunidad decente no pueden producir resultado político alguno, porque el lenguaje que deben usar para expresarlas los obliga a traicionarlas. La situación es aún más grave que la situación que preocupa a Rosenkrantz, porque en nuestro caso el excluido no puede ni siquiera levantar su voz en contra de la exclusión ${ }^{104}$. Su pretensión original no se escucha, pero tampoco se escucha su reclamo de que su pretensión original no se escucha. El derecho es ciego, y ciego incluso a su propia ceguera. El derecho, hablando a través de Rosenkrantz, tiene ojos para ver la situación de exclusión en la que quedaría el partidario de Nozick en una sociedad que constitucionaliza los derechos sociales, pero no tiene ojos para ver la exclusión del socialista cuyo alegato sólo puede ser formulado en el lenguaje de los derechos subjetivos si es distorsionado, transformado en un alegato distinto, liberal.

16. Quiero terminar esta parte comentando un ejemplo más de lo que hemos estado discutiendo. Gregorio Peces-Barba ha sostenido que el 'socialismo del futuro' debe prescindir de una de las demandas características del socialismo socialdemócrata, la idea del derecho al trabajo. La razón por la cual sostiene

\footnotetext{
${ }^{104}$ No me referiré aquí (más que en esta nota) al extraño naturalismo de Rosenkrantz respecto a la identidad de la comunidad política: Rosenkrantz parece creer que la comunidad política tiene límites naturales, y que en consecuencia la constitución debe ser una carta de compromiso entre todos aquellos que están de antemano incluidos (ibid 250). Pero desde luego no es así: la comunidad se constituye a sí misma, y por eso las constituciones se denominan, precisamente, 'constituciones' (véase Rubenfeld, Freedom and Time, 131-144). Cuáles diferencias son suficientes para estructurar, en términos de Schmitt, Concepto de lo Político, 56, la división propiamente política de 'amigo/enemigo' es en sí misma una cuestión política. En la segunda mitad del siglo XIX en Estados Unidos la creencia o no en la igualdad de blancos y negros fue suficiente para llevar el conflicto a su nivel máximo de intensidad (i.e. se convirtió en una cuestión política). En Chile durante los años 70 fue la diferencia marxista/antimarxista. El ejemplo muestra que no podemos dar una respuesta que cubra todos los casos (como las dan los que ingenuamente sostienen que la distinción amigo/enemigo es ajena a la política democrática), porque es la cuestión política por excelencia. Imputándole creencias que a mi me parecen razonables, imagino que Rosenkrantz sostendría que los americanos (del norte) tenían razón al insistir en el fin de la esclavitud como un criterio básico de definición de la comunidad, uno que justificaba someter (o expulsar) a los que no lo compartieran, y que los chilenos (de Pinochet) no tenían razón al definir la comunidad sobre la base del antimarxismo (tener razón=yo habría luchado con ellos). La constitución no representa el acuerdo de un grupo preexistente. Lo que hace es constituir a la comunidad política, como el grupo que adhiere a la decisión política fundamental. Por lo tanto Rosenkrantz no puede apelar al hecho del desacuerdo para justificar su abstinencia constitucional. Debe complementar su argumento epistémico con otro sustantivo que muestre que el desacuerdo sobre los derechos sociales no es suficiente para estructurar la distinción amigo/enemigo. No estoy diciendo que ese argumento no exista, sino objetando la tesis subyacente de Rosenkrantz: que no necesitamos formular ese argumento para decidir sobre la incorporación de los derechos sociales a la constitución.
} 
esto no es sino un argumento formal sobre la imposibilidad de positivar jurídicamente ese derecho, que en consecuencia 'no puede ser realmente derecho' ${ }^{105}$. Peces-Barba cree que reconocer el derecho al trabajo como derecho requiere dar a cada persona una acción que le permita forzar a alguna empresa la contratación y eso es, claro, absurdo. Pero eso sólo demuestra que es absurdo entender el derecho al trabajo como un derecho subjetivo accionable a una plaza de trabajo, y podemos fácilmente explicar por qué: porque del hecho de que sea justo (bueno, correcto, etc.) que alguien tenga trabajo no sigue sin mediación una respuesta a la pregunta de quién es el que está obligado a proveerlo. Como Peces-Barba cree (o parece creer) que los derechos sólo pueden significar lo que significan para el derecho, él pierde de vista la característica más importante del uso político de la idea de derechos. Peces-Barba, por ejemplo, cree que el uso de la expresión 'derechos' para criticar regímenes como la España franquista, la Rusia de Stalin o el Chile de Pinochet es un 'uso figurado [...], una extensión metafórica con la pretensión de reforzar el valor del objetivo moral' ${ }^{106}$. Al decir esto Peces-Barba ignora el hecho evidente de que este sentido 'metafórico' o 'figurativo' de los derechos ha sido, históricamente, su uso político primario: en las revoluciones francesa y americana, en el Chile de Pinochet, en la lucha por los derechos civiles en Estados Unidos durante los años '50 y '6o, etc. Si hay algo que es 'metafórico' o 'figurativo', es la asimilación de los derechos en sentido político a los derechos en sentido jurídico.

Partiendo de estos supuestos y conceptos, es obvio que el derecho al trabajo no tiene sentido. Pero Peces-Barba podría haber sido más caritativo con esa idea, al menos para evitar atacar un hombre de paja. A continuación sólo quiero hacer un par de observaciones sobre cómo podríamos entender el derecho al trabajo sin que nos llevara al absurdo que Peces-Barba cree es inevitable ${ }^{107}$.

\footnotetext{
${ }^{105} \mathrm{El}$ ofrece otras razones para rechazar el derecho al trabajo, algunas de las cuales son difíciles de entender. Aquí hay una, por ejemplo: 'seguir sosteniendo [ante el hecho de la imposibilidad del pleno empleo] que el trabajo es una exigencia para la autonomía moral del hombre sería condenar a una parte importante de la humanidad a la imposibilidad de su realización íntegra, de su independencia moral' (Peces-Barba, Derecho y Derechos Fundamentales, 421). Pero esto, como argumento para olvidarse del derecho al trabajo, no resiste análisis. El que dice, por ejemplo, que eliminar la pobreza, la tortura o la esclavitud es imprescindible para salvaguardar la dignidad humana, no está condenando a los que sufren esos flagelos a la indignidad.

106 ibid 415.

${ }^{107}$ Aquí no quiero defender la tesis del derecho al trabajo, sino sólo mostrar que ella puede tener un significado que no es el que le asigna Peces-Barba.
} 
El argumento que quiero simplemente mencionar lo ha expuesto J. Shklar en su American Citizenship. De acuerdo a Shklar, el trabajo no es un bien en sí mismo, sino es instrumental para la ciudadanía completa. El que trabaja contribuye al bienestar de la comunidad, por una parte, y recibe por ello un ingreso que le permite vivir con (cierta) independencia. Por eso el que es desempleado 'ha sido expulsado de la sociedad civil, reducido a ciudadano de segunda clase' ${ }^{108}$. Por consiguiente, tratándose del trabajo, debemos considerarlo

No como simplemente un interés entre otros, sino debería gozar de la primacía que un derecho puede reclamar en cualquier conflicto de prioridades políticas ${ }^{109}$.

Por eso, tiene sentido hablar del derecho al trabajo aun cuando no pueda ser protegido por tribunales. El compromiso con el derecho al trabajo no es un compromiso con un derecho subjetivo de cada persona a demandar coactivamente un puesto de trabajo, sino una manifestación del compromiso comunitario de considerar al empleo no como un dato macroeconómico más en la formulación de la política monetaria (o, aunque hoy por hoy sea anatema, la fiscal) sino como un aspecto central de la forma en que la comunidad entiende su responsabilidad de asegurar la igual ciudadanía de cada uno. Esto explica por qué no es sólo una metafórica o figurativa manifestación retórica decir que 'incluso si no es posible hacer que el derecho [al trabajo] sea completamente respetado, la conciencia del derecho puede tener un efecto político' ${ }^{110}$.

17. Que el discurso jurídico no puede acomodar los derechos sociales como puede acomodar los derechos civiles y políticos no es sólo un hecho casual: tiene que ver con el concepto mismo de derecho (subjetivo). Aun cuando la idea de derecho subjetivo propia del derecho privado ha mutado, se dice, en algo distinto cuando se utiliza para referirse no al derecho del comprador a que le entreguen la cosa vendida, sino al derecho 'humano' a la integridad física o a la participación política, lo que importa es lo que no ha mutado. Ya hemos visto que no basta querer separar, como Abramovich y Courtis intentaron hacerlo, la idea de derecho subjetivo de 'el contexto político-jurídico que culminó en la articulación técnica de esa noción' ${ }^{111}$, porque el concepto mismo

\footnotetext{
${ }^{108}$ Shklar, American Citizenship, 93.

${ }^{109}$ ibid, 99.

110 ibid, 101.

${ }^{111}$ Abramovich y Courtis, Derechos Sociales, 58.
} 
de derecho subjetivo, implica que el interés individual que el derecho protege triunfa (al menos típicamente) las aspiraciones comunitarias. Quien reclama un derecho se separa de la comunidad y afirma su derecho aun en contra de ella si es necesario. Por consiguiente, concebir la política como estructurada fundamentalmente por la idea de derechos subjetivos, por humanos que sean, implica rechazar la idea de una forma de asociación en la cual las personas se relacionan unas con otras no como agentes auto interesados sino unidos por vínculos de solidaridad y reciprocidad.

18. Por las razones anteriores es que todas las formas de socialización basadas en nociones de solidaridad y reciprocidad ${ }^{112}$ no pueden ser juridificadas $\sin$ traicionar su significado, es decir, sin ser tergiversadas o destruidas.

El primero ya fue mencionado: el caso de la solidaridad. Hacer algo respecto de otro porque el otro tiene derecho a exigirlo excluye el hacerlo por solidaridad. Esto no quiere decir que yo no pueda hacer por solidaridad algo a lo que de todos modos el otro tiene derecho. Pero sí quiere decir que ambas descripciones ('actuó para satisfacer un derecho del acreedor'/'por solidaridad') son incompatibles.

Lo mismo ocurre en el matrimonio. El derecho constituye y regula el contrato de matrimonio, estableciendo derechos y obligaciones para los cónyuges. Pero los cónyuges no pueden invocar esos derechos entre sí sin producir una subversión completa de la relación entre ellos; el derecho asfixia, de este modo, el amor entre los cónyuges. No se trata de que el derecho aumente o disminuya la injusticia sufrida por alguna de las partes; eso dependerá de las partes no estipuladas del ejemplo ${ }^{113}$. En otras palabras,

La substancia del reclamo puede ser indispensable para un matrimonio feliz y amoroso en el mundo moderno. Es el hecho de esgrimirla como un derecho - es decir, como algo que alguien exige de modo perentorio, agresivo y adversarial contra el otro - lo que nos llevaría [a decir que algo anda mal en ese matrimonio] ${ }^{114}$.

El argumento no implica, por tanto, ni que no deba haber regulación legal del matrimonio ni que la regulación legal del matrimonio no deba crear derechos para los cónyuges. Pero sí implica que si por alguna razón nosotros

\footnotetext{
${ }^{112}$ Uso la noción de 'reciprocidad' en el sentido de Cohen, "Vuelta a los principios socialistas", 160-163. ${ }^{113}$ e.g. si la mujer invoca su derecho a desarrollar su propia carrera profesional asfixiada por la división sexual del trabajo establecida al interior de su matrimonio, podemos celebrar que el derecho irrumpa en esa relación subvirtiéndola, pero eso no cambia el hecho de que la irrupción del derecho la ha subvertido. ${ }^{114}$ Waldron, "When justice replaces affection", 372-3.
} 
llegáramos, en tanto cónyuges, a concebir el matrimonio, con Kant, como un contrato $^{115}$, y creyéramos que la manera adecuada de concebir las posiciones de los cónyuges por los propios cónyuges fuera en términos de derechos y obligaciones, entonces habríamos perdido la capacidad de relacionarnos unos con otros a través de esa modalidad especial que conocemos como matrimonio. El argumento, por si mismo, es naturalmente agnóstico sobre si esto es una cosa que debe ser celebrada o resistida.

La amistad, por último, tampoco puede ser descrita en términos de derechos y obligaciones sin pérdida de significado. Al igual que en los casos anteriores, no se trata de que no tenga sentido describir la posición de un amigo en términos de derechos y deberes (derecho a no ser traicionado por el otro, etc); de lo que se trata es que si nos convenciéramos de que la amistad debe ser primariamente entendida en términos de derechos y obligaciones ésta habría cambiado radicalmente.

En los tres casos, lo importante es distinguir el caso de una relación que puede ser concebida utilizando el lenguaje del derecho de una relación que puede ser concebida primariamente en términos jurídicos y permanecer fiel a sí misma. 'Primariamente' aquí indica el modo de auto comprensión de las partes en primera persona. Ello no obsta a que un observador (por ejemplo, un sociólogo) describa en tercera persona las relaciones de amistad en términos de derechos y deberes. Lo mismo ocurre, como hemos visto, en el caso del matrimonio: el argumento presentado más arriba no se opone a que un profesor de derecho civil describa el matrimonio en términos de los derechos subjetivos de los cónyuges, sólo indica que si éstos entienden su relación en esos términos ya no existe entre ellos lo que nosotros llamamos 'matrimonio' en sentido no legal sino substantivo, i.e. como una relación amorosa entre dos personas. 19. La pregunta central para nuestros propósitos es: ¿es la ciudadanía una forma de relación no juridificable? La forma de comunidad a la que apela la idea de derechos sociales, en tanto 'conquista clamorosa de la izquierda' es como la solidaridad, el amor de los cónyuges o la amistad; no puede ser juridificada sin ser desnaturalizada. Los derechos sociales apelan a una idea de comunidad cuyo

requerimiento central es que a las personas les importe y, cuando sea necesario y posible, se

${ }^{115}$ Kant, Metafisica de las Costumbres, $\$ 24$. 
preocupen de la suerte de los demás. Y también que les importe preocuparse los unos de los otros $^{116}$

Esta noción de comunidad es incompatible con una que concibe a sus miembros primariamente como portadores de derechos, porque expresiones como

'tengo un derecho...' o 'no tienes derecho a...' [...] evocan una guerra latente y despiertan el espíritu de contienda. Ubicar la noción de derechos al centro de los conflictos sociales es inhibir cualquier posible impulso a la caridad en ambos bandos ${ }^{117}$.

Los individuos que se conciben a sí mismos primariamente como portadores de derechos son los individuos que concurren al mercado: individuos para los cuales los otros son amenazas, amenazas contra las cuales deben estar defendidos ${ }^{118}$. Los derechos son esas armas de defensa. Por eso los abogados (acostumbrados como están a mirar las relaciones interpersonales en términos de lo que Oliver W. Holmes llamaba 'el hombre malo' ${ }^{119}$ ) insisten en la exigibilidad como marca característica de un derechos subjetivo: para qué sirve un arma de defensa que no es útil para exigir respeto? En efecto, Los derechos siempre son afirmados en un tono de contienda; y cuando este tono es adoptado debe estar apoyado por la fuerza, de otro modo sería motivo de burla ${ }^{120}$.

En un contexto en el cual la reflexión y discusión políticas se concibe a los ciudadanos primariamente como portadores de derechos, quienes creen que es posible otra forma de comunidad están como el león del que hablaba Ludwig Wittgenstein: 'si pudiera hablar, no lo entenderíamos' ${ }^{121}$.

\footnotetext{
${ }^{116}$ Cohen, “¿Por qué no el socialismo?” 72.

${ }^{117}$ Weil, "La persona y lo sagrado", 28. Véase adicionalmente Atria, "La hora del derecho", supra n. 72.

${ }^{118}$ Cohen, "Vuelta a los principios socialistas", 161.

${ }^{119}$ Holmes, "Path of the law", 459 [19].

${ }^{120}$ Weil, "La persona y lo sagrado", 26.

${ }^{121}$ Wittgenstein, Philosophical Investigations, IIxi, p. 221e.
} 


\section{Referencias}

Abramovich, V y Courtis, C.: Los Derechos Sociales como Derechos Exigibles (Madrid: Trotta, 2002).

Altman, A: The Critical Legal Studies Movement (Princeton, NJ: Princeton University Press, 1990).

Arendt, H: The Human Condition (Chicago, IL: University of Chicago Press, 1958); también La Condición Humana (Barcelona: Paidós, 1998), traducido por R G Novales.

_-On Revolution (Harmondsworth: Penguin, 1977; edn orig 1963); también Sobre la Revolución (Madrid: Alianza, 1988), traducido por P Bravo.

— Los Orígenes del Totalitarismo (Madrid: Taurus, 1998; edn orig 1951), traducido por G Solana.

Bankowski, Z: Living Lawfully (Dordrecht: Kluwer, 2001).

Bentham, J: Rationale of Judicial Evidence (Edinburgh: William Tait, 1843; edn orig 1827).

Bobbio, N: Derecha e Izquierda (Madrid: Taurus, 1996), traducido por A Picone.

— El Positivismo Jurídico (Madrid: Debate, 1998; edn orig 1961), traducido por R de Asís y A Greppi.

Böckenförde, W: "Origen y cambio del concepto de Estado de Derecho" (1969), en Böckenförde, W: Estudios sobre el Estado de Derecho y la Democracia (Madrid: Trotta, 2000), traducido por R Agapito.

Böhmer, M: "La corte de los ' 80 y la corte de los '90: un diálogo sobre el rule of law en Argentina", en A J D'Alessio, J J Alvarez et al: Estado de Derecho y Democracia (Buenos Aires: Editores del Puerto, 2001).

Campbell, T: The Left and Rights (London: Routledge and Kegan Paul, 1983).

- The Legal Theory of Ethical Positivism (Aldershot: Darmouth, 1996).

Campbell, T y Goldsworthy, J. (eds): Judicial Power, Democracy and Legal Positivism (Aldershot: Darmouth, 2000).

Christodoulidis, E: "The Inertia of Institutional Imagination: A Reply to Roberto Unger”, en 59 Modern Law Review (1996): 377-397. ,Law and Reflexive Politics (Dordrecht: Kluwer, 1998).

Cohen, G A: Self-Ownership, Freedom and Equality (Cambridge: Cambridge University Press, 1995).

¿¿Por qué no el socialismo?” en Gargarella, R. y Ovejero, F. (eds): Razones para el Socialismo (Barcelona: Paidos, 2002).

,"Vuelta a los principios socialistas", en Gargarella, R. y Ovejero, F. (eds): Razones para el Socialismo (Barcelona: Paidos, 2002). 
Correa Sutil, J: "Cenicienta se queda en la fiesta: el poder judicial en la década de los 90", en I Drake y P Jaksic (eds): El Modelo Chileno (Santiago: LOM, 1999).

Dabin, J: El Derecho Subjetivo (Madrid: Editorial Revista de Derecho Privado, 1955), traducido por F J Osset.

Dworkin, R: "Rights as Trumps" (1981), en J Waldron (ed): Theories of Rights (Oxford: Oxford University Press, 1984).

_L Law's Empire (London: Fontana, 1986); también El Imperio de la Justicia (Barcelona: Gedisa, 1988), traducido por C Ferrari.

Elster, J: "Is there a right to work?" en A Gutmann (ed): Democracy and the Welfare State (Princeton, NJ: Princeton University Press, 1988).

Esping-Andersen, G: The Three Worlds of Welfare Capitalism (Oxford: Polity Press, 1990).

González, F: "Evolución y perspectivas de la red universitaria sudamericana de acciones de interés público", en F González y F Viveros (eds): Defensa Jurídica del Interés Público (Santiago: Universidad Diego Portales, 1999).

Goodin, R, B Headley et al: The Real Worlds of Welfare Capitalism (Cambridge: Cambridge University Press, 1999).

Habermas, J: Facticidad y Validez (Madrid: Trotta, 1998; edn orig 1992), traducido por M Jiménez.

Hart, H L A: The Concept of Law (Oxford: Clarendon Press, 1994; edn orig 1961); también El Concepto de Derecho (Buenos Aires: Abeledo-Perrot, 1963), traducido por G Carrió.

Hayek, F: Rules and Order (London: Routledge and Kegan Paul, 1973).

Hobbes, T: Leviathan (Oxford: Oxford University Press, 1965; edn orig 1651); también Leviatán (México: Fondo de Cultura Económica, 1987), traducido por M Sánchez.

Hohfeld, W N: Conceptos Jurídicos Fundamentales (México: Fontamara, 2001; edn orig 1923).

Holmes, O W: "The path of the law", en 10 Harvard Law Review (1897): 457; también 'La Senda del Derecho' (Buenos Aires: Abeledo-Perrot, 1988), traducido por E A Russo.

Holmes, S: "Liberal Guilt. Some theoretical origins of the welfare state", en J D Moon (ed): Responsibility, Rights and Welfare (Boulder, CO: Westview Press, 1988).

Jefferson, T: Writings (New York: The Library of America, 1984).

Jones, P: Rights (London: MacMillan, 1994).

Kant, I: La Metafisica de las Costumbres (Madrid: Tecnos, 1994; edn orig 1790), traducido por A Cortina y J Conill.

Kelley, D: A Life of One's Own (Washington DC: Cato Institute, 1998). 
Kelsen, H: Teoría Pura del Derecho (México: Porrúa, 1991; edn orig 1960), traducido por R J Vernengo.

Kramer, M: Rights without Trimmings (Oxford: Oxford University Press, 2000).

Laporta, F: "El concepto de derechos humanos", en 4 DOXA (1987): 23-46.

Locke, J: Two Treatises on Government (New York: Mentor, 1965; edn orig 1689); también Dos Ensayos sobre el Gobierno Civil (Madrid: Espasa Calpe, 1991), traducido por F Giménez.

Marshall, T: Citizenship and Social Class (London: Pluto, 1992; edn orig 1950); también Ciudadanía y Clase Social (Madrid: Alianza, 1998), traducido por P Linares.

Marx, K: Critique of the Gotha program (Cambridge: Cambridge University Press, 1996; edn orig 1875), traducido por T Carver.

McLellan, D (ed): Marx's Grundrisse (London: MacMillan, 1971).

Montesquieu: Del Espiritu de las Leyes (Buenos Aires: Heliasta, 1984; edn orig 1748), traducido por N Estevanez.

Nickel, J: "Is there a human right to employment?" en 10 Philosophical Forum (1978-9): 149-70.

Nozick, R: Anarchy, State and Utopia (Cambridge, MA: Harvard University Press, 1974); también Anarquía, Estado y Utopía (México: Fondo de Cultura Económica, 1990), traducido por R Tamayo.

O'Neill, O: Bounds of Justice (Cambridge: Cambridge University Press, 2000).

Pashukanis, E: Law and Marxism: a general theory (London: Pluto Press, 1978)1929), traducido por B Einhorn.

Peces-Barba, G: Derecho y Derechos Fundamentales (Madrid: Centro de Estudios Constitucionales, 1993).

Prieto, L: Estudios sobre Derechos Fundamentales (Madrid: Debate, 1990).

Rawls, J: A Theory of Justice (Cambridge, MA: Harvard University Press, 1971); también Teoría de la Justicia (México: Fondo de Cultura Económica, 1985), traducido por M D González.

— Political Liberalism (New York, NY: Columbia University Press, 1993); también Liberalismo Político (México: Fondo de Cultura Económica, 1995), traducido por S R Madero.

,"Two Concepts of Rules" (1955), en S Freeman (ed): John Rawls. Collected Papers (Oxford: Clarendon Press, 1999); también 'Dos Conceptos de Regla', en P Foot (ed): Teorías sobre la Ética (México: Fondo de Cultura Económica, 1974), traducido por M Arbolí.

Raz, J: Practical Reason and Norms (Princeton: Princeton University Press, 1992; edn orig 1975); también Razón Práctica y Normas (Madrid: Centro de 
Estudios Constitucionales, 1992), traducido por J Ruiz Manero.

Rosenkrantz, C: "La pobreza, la ley y la constitución", en A Bullard, J Couso et al: El Derecho como Objeto e Instrumento de Cambio Social (Buenos Aires: Editores del Puerto, 2003).

Rousseau, J J: Contrato Social (Madrid: Espasa-Calpe, 1975)1762), traducido por F de los Ríos.

Rubenfeld, J: Freedom and Time (New Haven, CT: Yale University Press, 2001).

Schmitt, C: Teoría de la Constitución (Madrid: Alianza, 1992; edn orig 1928), traducido por F Ayala.

_El Concepto de lo Político (Madrid: Alianza, 1998; edn orig 1932), traducido por R Agapito.

Schwartz, H: The Struggle for Constitutional Justice in Post-Communist Europe (Chicago, IL: Chicago University Press, 2000).

Shklar, J: Legalism (Cambridge, Mass: Harvard University Press, 1986; edn orig 1964).

—,American Citizenship. The quest for inclusion (Cambridge MA: Harvard University Press, 1991).

Smart, J C C: "Extreme and Restricted Utilitarianism" (1956), en P Foot (ed): Theories of Ethics (Oxford: Oxford University Press, 1967); también 'Utilitarismo extremo y restringido', en Foot, P (ed): Teorías sobre la Ética (México: Fondo de Cultura Económica, 1974), traducido por M Arbolí.

Smith, A: An Inquiry into the Nature and Causes of the Wealth of Nations (Indianapolis: Liberty Fund, 1981; edn orig 1776).

Unger, R M: The Critical Legal Studies Movement (Cambridge, MA: Harvard University Press, 1983). -, What Should Legal Analysis Become (London: Verso, 1994).

Van Caenegem, R C: Judges, Legislators and Professors (Cambridge: Cambridge University Press, 1987).

Villey, M: "Los orígenes de la noción de derecho subjetivo", en M Villey: Estudios en Torno a la Noción de Derechos Subjetivo (Valparaíso: Ediciones Universitarias de Valparaíso, 1976), traducido por A Guzmán.

Waldron, J: "Karl Marx's 'On the jewish question'“, en J Waldron (ed): Nonsense upon Stilts (London: Methuen \& Co, 1987).

,"Natural rights in the seventeenth and eighteenth centuries", en J Waldron (ed): Nonsense upon Stilts (London: Methuen \& Co, 1987).

,"Nonsense upon stilts? - A reply", en J Waldron (ed): Nonsense upon Stilts (London: Methuen \& Co, 1987).

"A right to do wrong?" en J Waldron: Liberal Rights (Cambridge: Cambridge University Press, 1993). 
_- "When justice replaces affection: the case for rights" (1988), en J Waldron: Liberal Papers (Cambridge: Cambridge University Press, 1993). ,Law and Disagreement (Oxford: Clarendon Press, 1999).

Weil, S: Echar Raices (Madrid: Trotta, 1996; edn orig 1949), traducido por J R Capella.

_ "Estudio para una declaración de las obligaciones respecto al ser humano" (1957), en S Weil: Escritos de Londres y Últimas Cartas (Madrid: Trotta, 2000), traducido por M Larrauri.

__La persona y lo sagrado" (1950), en S Weil: Escritos de Londres y Últimas Cartas (Madrid: Trotta, 2000), traducido por M Larrauri.

Weinrib, E: The Idea of Private Law (Cambridge, MA: Harvard University Press, 1995).

Wittgenstein, L: Philosophical Investigations (Oxford: Blackwell, 1958), traducido por G E M Anscombe.

Zagrebelski, G: El Derecho Dúctil (Madrid: Trotta, 1995; edn orig 1992). 